\title{
COMMENTS
}

\section{THE PER SE ILLEGALITY OF PRICE-FIXING-SANS POWER, PURPOSE, OR EFFECT}

In Kiefer-Stewart Co. v. Seagram \& Sons, Inc., ${ }^{1}$ the Supreme Court held illegal per se a maximum resale price-fixing agreement between producers (a parent corporation and its wholly owned subsidiary), thereby filling some of the few remaining gaps in the law against price-fixing agreements. Although a broad dictum in United States v. Socony-Vacuum Oil Co. states that under the Sherman Act ${ }^{2}$ "a combination formed for the purpose of and with the effect of raising, depressing, fixing, pegging or stabilizing the price of a commodity in interstate or foreign commerce is illegal per se," ${ }^{, 3}$ no antitrust precedent had directly determined that sellers attempting to hold down the resale prices of their products were restraining trade. ${ }^{4}$ The Miller-Tydings Amendment ${ }^{5}$ does not exempt maximum resale price-fixing; but under a test of "reasonableness" the arrangements in the instant case might have been upheld as a weapon against monopolistic combinations of distributors. The rule against price-fixing, however, appears to have become too stringent to admit promotion of competition as an effective justification. ${ }^{6}$ Without proof of market power or effect and solely on the basis of a jury finding of conspiracy between the defendants to fix maximum resale prices on their products, the Court held their action violative of Section 1 of the Sherman Act. Based upon probably the first set of facts to require a square holding by the Supreme Court that price-fixing agreements are literally illegal per se, this decision deserves further scrutiny as a precedent which promises to play a significant role in future antitrust prosecutions. ${ }^{7}$

1340 U.S. 211 (1951).

226 Stat. 209 (1890), as amended, 15 U.S.C.A. $\$ 1$ (1951).

310 U.S. 150, 223 (1940).

4Sellers' maximum price-fixing must, of course, be distinguished from the monopsonistic practices of buyers who compel sale to themselves at prices lower than those which the seller would obtain under competitive conditions. The latter, more clearly apposite to sellers' minimum price-fixing, was declared illegal within the per se rule in Mandeville Island Farms, Inc. v. American Crystal Sugar Co., 334 U.S. 219 (1948), and may have been the type of price depression envisoned by Justice Douglas when the Socony-Vacuum opinion was written.

550 Stat. 693 (1937), as amended, 15 U.S.C.A. $\$ 1$ (1951). This amendment exempts only "contracts or agreements prescribing minimum prices for resale" under specified conditions.

- Kiefer-Stewart implicitly rejects a dictum in Spencer v. Sun Oil Co., 94 F. Supp. 408, 412 (Conn., 1950), to the effect that plaintiff-retailers' illegal price maintenance agreement was a defense to their suit for treble damages under the antitrust laws.

${ }^{7}$ The Court of Appeals opinion in favor of the distillers contains a fairly comprehensive exposition of the facts. Kiefer-Stewart Co. v. Seagram \& Sons, Inc., 182 F. 2d 228, 229-34 (C.A. 7th, 1950). 
I

Shortly after termination of OPA ceilings in October 1946 and following a meeting of the Indiana Wholesale Liquor Dealers Association, ${ }^{8}$ Kiefer-Stewart and every other liquor wholesaler in Indiana filed identical schedules of increased prices with state authorities. The new schedules were arrived at by computing the customary fifteen per cent wholesaler's mark-up on the basis of costs plus taxes, whereas OPA regulations had required the computation to be made exclusive of taxes added during the period of OPA control. Subsequently (November 6,1946$)$, Seagram, which had spent some $\$ 500,000$ advertising against inflated whisky prices, ${ }^{9}$ notified Indiana wholesalers that wholesale prices were to be kept at OPA levels. Upon the wholesalers' concerted refusal to comply, Seagram suspended all shipments to Indiana distributors. ${ }^{10}$ Immediately prior to this action Kiefer-Stewart and Calvert Distilling Company, a wholly owned subsidiary of Seagram, ${ }^{\text {II }}$ had concluded negotiations giving Kiefer-Stewart a Calvert distributorship; and even after Seagram had severed relations, Calvert representatives had assured Kiefer-Stewart that their relationship would be unaffected by the parent company's defection and that cases of liquor would be delivered as promised..$^{12}$ Within a week the deal was called off, and the jury found that Calvert's reversal of position was the result of an agreement with Seagram and not independent action..$^{13}$ By February of the next year all Indiana wholesalers except Kiefer-Stewart had filed notification of a return to the OPA method of calculating mark-ups and by July 1, 1947, had entered into fair trade contracts with both distillers which stipulated similar minimum wholesale prices. ${ }^{14}$

${ }^{8}$ This group has a membership fluctuating between twenty-seven and thirty members representing all the whisky wholesalers operating in Indiana. See Transcript of Record at 155, ibid.

${ }^{9}$ Competition:Liquor Price Key, Business Week, at 50 (Nov. 16, 1946), which also reported that "[w] marked on by other importers ranged anywhere from nearly $\$ 5$ to more than $\$ 29$ a case at wholesale." Ibid., at 54 .

${ }^{10}$ It is doubtful that many Seagram sales were lost during the siege since liquor retailers and wholesalers generally carry large inventories even of fast-moving brands.

11 Distillers Corporation-Seagrams, Itd., a Canadian corporation not a party to this litigation, wholly owns Joseph E. Seagram \& Sons, Inc., an Indiana corporation which is both an operating and holding company and, in the latter capacity, wholly owns Calvert Distilling Company, a Maryland corporation. Calvert common stock, originally held by the Canadian corporation was transferred to the Indiana company on April 9, 1945, and in the trial stage the wholesaler claimed this acquisition was unlawful but dropped the charge on appeal. $182 \mathrm{~F}$. 2d 228, 229 (C.A. 7th, 1950).

12 Transcript of Record at 82, ibid.

${ }^{13}$ Reversing the Court of Appeals, the Supreme Court concluded that there was sufficient evidence to warrant the jury finding.

14 Despite allegations in the Kiefer-Stewart briefs, these contracts were a logical extension of the original policy since competition for retail business is sufficiently strong among Indiana wholesalers to make minimum prices maximum prices. Besides, a regulation of the Indiana Alcoholic Beverage Commission, effective July 1, 1947, made fair trade contracts a prerequisite 
An adequate understanding of factors motivating the parties litigant may be had only by going behind the record to the power relationships and the business context in which they functioned. Since repeal of prohibition four major concerns have, as a group, consistently controlled two-thirds of the whisky business and a similar proportion of the all-important inventories of aging whiskies..$^{15}$ Generally there is no price competition among the Big Four who confine their conflict to marketing techniques and the battle of brands..$^{16}$ Although the industry itself attributes high-level price rigidity to its relatively fixed number of consumers, ${ }^{17}$ its social conscience, ${ }^{18}$ and the danger of losing prestige and volume

to "price and brand" advertising by distillers. Brief for Respondents in the Supreme Court 24 n.11 and Transcript of Record at 215, Kiefer-Stewart Co. v. Seagram \& Sons, Inc., 340 U.S. 211 (1951).

15 "The competitive pattern was set long before the war by the four major distillersSchenley Distillers Corp., and Distillers Corp.-Seagrams, Ltd., National Distillers Products Corp., and Hiram Walker-Gooderham \& Worts, Ltd.-which have dominated the industry for the last ten years. Known to retailers as 'the Axis,' these four now hold more than $70 \%$ of the U.S. whiskey supply." The Whiskey Rebellion, 35 Fortune, No. 6, at 141 (June 1947). "[I]n the brief fifteen years of the industry's existence since repeal, the intensity of brand competition has resulted in a measure of concentration familiar in many American industries. . . . Five leading brands, which before the war did 20 per cent of the total U.S. business now do 50 per cent of the business. The Big Four distillers now get about 75 per cent of the business, make about half the whiskey, and hold about 60 per cent of the inventories." Seagram In the Chips, 38 Fortune, No. 3, at 97 (Sept. 1948). For similar statistics consult: Corrado, Distillers Prepare for Bigger Sales, 25 Barron's, at 13 (Nov. 26, 1945); 6 Hearings before the Temporary National Economic Committee, Pub. Res. 113, 76th Cong. 1st Sess. 2435-40, Exhibits 399-402 at 2678-81 (1939); Dobbs, Liquors Facing Price War?, 84 Magazine of Wall Street at 283 (June $18,1949)$.

${ }^{16}$ TNEC Hearings, op. cit. supra note 15, at 2562-68, 2519 (testimony of W. W. Wachtel, president of Calvert Distilling and of James Friel, vice-president of Distillers Corp.-Seagrams, Ltd.). "Most price-slashing was done at the retail level, and it was usually the retailers' profit margins that were affected. . . . [C]ompetition has largely been removed from the price arena and concentrated in such intangibles as flavor and quality." Bleiberg, Distillers See Long Life for Fair Trade, 28 Barron's at 10 (Nov. 8, 1948).

${ }^{17}$ Seagram in the Chips, 38 Fortune, No. 3, at 97 (Sept. 1948). Although it may be true that the whisky market is relatively inelastic, apparent consumption has varied greatly over the years. Since repeal of prohibition consumption on a per capita basis has fluctuated from a low of .93 wine-gallons of distilled spirits in 1939 to 1.39 wine-gallons in 1946 back to 1.02 in 1949 . Statistical Abstract of U.S 787 (1950). Total consumption was $89,676,000$ wine-gallons in 1935 ; $144,996,000$ in $1940 ; 190,148,000$ in $1942 ; 145,524,000$ in $1943 ; 230,976,000$ in $1946 ; 171,012,000$ in 1948; 190,343,000 in 1950. Computed from Dep't of Commerce, 1949 Statistic SupplementSurvey of Current Business 134 (1949); and Dep't of Commerce, Survey of Current Business S-27 (June 1951).

${ }^{18}$ Persons at every level of the industry disclaim any intention of bringing new consumers into the market; even advertising seems intended for those who have already imbibed-no one gets that "first exhilarating feeling," one merely "switches" to Calvert. Undoubtedly a fear of "dry" legislation underlies this approach; and for the same reason temperance seems also to be a main theme. "The per capita consumption of liquor will vary somewhat with the national income, but the industry chooses discreetly to do little or nothing to increase this consumption. ... In fact it preaches moderation. The main struggle therefore is among its members for the available business.... Thus distillers meet each other warily within the cage of relatively fixed consumption." Ibid. See also Seagram Bars Cut in Domestic Prices, N.Y. Times $\$ 1$, p. 37, col. 3 (July 20, 1949); and Abrahamson, Whiskey-The Incidence of Public Tolerance in Price Policy in Hamilton, Price and Price Policies 395, 407-8 (1938). 
from reduced or fluctuating prices, ${ }^{19}$ "stickiness" and nonprice competition are probably the familiar results of market domination by a few firms. ${ }^{20}$

After tasting the bitter dregs of price wars in the middle Thirties, retailers and wholesalers, who had absorbed a major portion of the losses, ${ }^{21}$ began to reap some of the advantages of combination under the fair trade laws. When whiskymakers, seeking greater volume, showed reluctance to enforce price maintenance, ${ }^{22}$ some state legislatures made fair trade mandatory for the industry ${ }^{23}$

${ }^{19} \mathrm{Mr}$. Gene Tunney, chairman of the board, American Distilling Co., explained that distillers supported fair trade because "it ruins the reputation of an article if it gets into constant war over price. . . . I don't think it does anybody's product any good to get in price wars, in the public mind." TNEC hearings, op. cit. supra note 15, at 2571. Similar statements were made by representatives of Schenley Distilling Corp. and National Distillers Corp. in personal interviews. It is quite possible, of course, that volume is lost because influential retailers refuse to push price-cut brands.

20 "The prices of all domestic products of Joseph E. Seagram \& Sons, Inc., will remain unchanged for the balance of the year, Gen. Frank $R$. Schwengel, company president declared today.... He emphasized the 'firm price' policy is not a new one with the company, pointing out that domestic brands have not changed in price since 1936. The higher price per bottle to the consumer is due entirely to tax increases which now constitute more than 50 per cent of the retail price of liquor, he said." Seagram Bars Cut in Domestic Prices, N.Y. Times $\S 1$, p. 37, col. 3 (July 20,1949).

"The outstanding virtue of a system of private enterprise, therefore, arises out of a kind of mutual confidence game. But if there are few enough sellers in the market to enable each to watch all the others, the play may slow down: if a price cut will be quickly met, and no lasting benefit secured, why make it at all? To the extent that the sellers anticipate each others' reactions and become of one mind, they behave like one seller, a monopolist." Adelman, Effective Competition and Antitrust Laws, 61 Harv. L. Rev. 1289, 1299 (1948). Without adopting this author's causal analysis, it is not difficult to ascertain numerous ways in which knowledge of competing prices is available to members of the liquor industry-filing requirements with state beverage commissions and "fair trade" itself provide excellent methods of "signal-calling" without the appearance of collusion. See Irvin, Distilled Spirits, pt. IV, p. 9 (Foote, Cone \& Belding Res. Dep't 1948); Trade Association Statistics and the Anti-Trust Laws, 18 Univ. Chi. L. Rev. 380 (1951); see note 153 infra.

${ }^{21}$ Bleiberg, Distillers See Long Life for Fair Trade, 28 Barron's at 10 (Nov. 8, 1948); FTC, Report on Resale Price Maintenance, c. VIII (1945).

22 Although lack of diligence in prosecuting violators has ordinarily been held to be no defense to prosecution for violation of fair trade laws, National Distillers Products Corp. v. Columbus Circle Liquor Stores, 166 N.Y. Misc. 719, 2 N.Y.S. $2 d 319$ (S.Ct., 1938), Calvert Distilling Co. v. Gold's Drug Stores, 123 N.J. Eq. 458, 198 Atl. 536 (1938), Calvert Distillers Corp. v. Stockman, 26 F. Supp. 73 (E.D.N.Y., 1939), nevertheless the cases are instructive as to distillers' general attitudes toward fair trade laws. Cases in which actual abandonment of price maintenance and encouragement of price-cutting by a distiller have been successfully employed as a defense to discriminatory fair trade enforcement by that same distiller are numerous. Wilson Distilling Co. v. Stockman, 11 N.Y.S. 2d 51 (S.Ct., 1939); and cases cited and analyzed in American Fair Trade Council, Resale Price Maintenance 25 (1942). See also FTC, Report on Resale Price Maintenance, c. VII, at 358, 364-67, 396 (1945); The Whiskey Rebellion, 35 Fortune, No. 6, at 143 (June 1947).

${ }^{23} 2$ CCH Trade Reg. Rep. $\{7375$ (1945) lists New Jersey, Arizona, California, Illinois, Kentucky, New Mexico, and New York as states with mandatory fair trade laws applicable to the liquor industry. The Illinois and New York mandatory liquor fair trade laws were recently declared unconstitutional on technical grounds. Illinois Liquor Control Commission v. Chicago's Last Liquor Store, 403 IIl. 578, 88 N.E. 2d 15 (1947); Levine v. O’Connell, 275 App. Div. 217, 88 N.Y.S. 2d 672 (1949) (N.Y. Alcoholic Beverage Control Law § 17(12)) (Supp., 1949). For an account of other legislative aids to retail monopolies, see Sales Below Cost Prohibitions: Private Price Fixing under State Law, 57 Yale L.J. 391 (1948). 
But, even when the state did not step in, distillers soon learned that such reluctance could be costly. Being dependent upon consumer appeal based on nonprice distinctions such as brand, quality, etc., the whisky producer finds it necessary to cater to those who control his ultimate outlets. ${ }^{24}$ Like druggists, ${ }^{25}$ organized liquor retailers have made and broken even nationally advertised brands by their own promotional activities. ${ }^{26}$ Distillers, often precluded by statute (as in Indiana ${ }^{27}$ ) from entering the distribution field, can ill-afford to incur retailers' enmity and generally accede to their demands for price maintenance at levels permitting high retail mark-ups. ${ }^{28}$ Wholesalers, on the other hand, do not occupy a similarly strategic position because they do not influence the consuming public directly. ${ }^{29}$ Distillers' threats of withdrawing distributorships in branded whiskies are sufficiently effective to bring recalcitrant jobbers into line; ${ }^{30}$ and the latter are often made unwilling parties to discount "deals"

24 "Some distillers' approach to resale price maintenance is that retailers practically boycott goods not under retail price maintenance and therefore in order to retain good will the distiller must conform." FTC, op. cit. supra note 21, at 393 (see same authority at 361, 364-67).

${ }^{25}$ FTC, op. cit. supra note 21 , at 166-218, describes the tremendous pressure retail drug organizations have managed to exert upon manufacturers in compelling resale price maintenance.

${ }^{28}$ Concrete instances of retail organization triumphing over a Big Four distiller who favored price-cutting at the retail level are described in FTC, op. cit. supra note 21, at 363-67. Similarly successful price maintenance by retailers coercing reluctant distillers seems to have provided the background for Calvert Distilling Co. v. Brandon, 24 F. Supp. 857 (W.D.S.C., 1938), and cases cited note 22 supra. According to Ross Federal Research Corp., Consumer Buying Habits with Regard to Alcoholic Beverages (1937), $41.68 \%$ of the customers of package stores in nineteen large cities relied wholly on the recommendation of the retailer in purchasing liquor and $48.14 \%$ of customers at bars relied on the bartender's judgment, while in the latter case it was estimated that of those customers ordering straight drinks by specific brand $44.10 \%$ could be "switched" and of those ordering mixed drinks $48.74 \%$ could be "switched." See also Abrahamson, op. cit. supra note 18, at 399-400, 403 n.1, 413-16.

${ }^{27}$ Ind. Stat. Ann. $\$ 12-514$ (Burns, 1933). Distillers presently seem desirous of entering the field at least at the wholesale level, The Whiskey Rebellion, 35 Fortune, No. 6, at 140, 143 (June 1947). Seagram once threatened New York City distributors by cutting of supply for a short time and obtaining a license for its own wholesale outlet, Sea-Cal-Frank, which apparently is still good although as yet unexercised. Business Week at 37 (Dec. 11, 1948).

${ }^{28}$ FTC, op. cit. supra note 21, at 358 . Perhaps the greatest mystery in the liquor industry is exactly why distillers have promoted or enforced resale price maintenance. The FTC Report concludes that retail pressure is sufficient; and this is the position here adopted. On the other hand, the view entertained by many members of the industry personally interviewed is that retailers in the Midwest are generally too weak to maintain concerted action against distillers. Another motive for resale price maintenance, which might be responsible for this very condition, could be preventing the growth of retail units (similar to A \& $\mathrm{P}$ ) capable of bargaining on a par. Finally, resale price maintenance may simply be another method of keeping big competitors in line. See note 20 supra, and note 153 infra.

${ }^{20}$ Wholesalers must also overcome the effect upon retailers of "missionary" work by distillers' representatives. W. W. Wachtel, President of Calvert, in his testmony before the TNEC emphasized the importance of promotional work on the retail level. TNEC hearing, op. cit. supra note 15 , at $2551,2566-67$.

${ }^{30}$ As well, many wholesalers are "tied" to distillers who have granted quite substantial credit to them. Ibid., at $2509,2520$. 
benefitting retailers. ${ }^{31}$ Unlike retailers, whisky wholesalers are few in number and their profit margins are thin. ${ }^{32}$

In the light of this factual background it may be useful to reconstruct the strategy of the parties in Kiefer-Stewart v. Seagram. Indiana wholesalers saw in the termination of OPA an opportunity by concerted action to increase margins greatly reduced by wartime taxation. Seagram and Calvert, on the other hand, faced a declining post-war consumer market. ${ }^{33}$ Acquiescence to wholesalers' demands would have inevitably resulted in higher retail prices and possibly a large drop in volume and profits for the distillers. Adopting what may have seemed their only rational course, Seagram and its subsidiary exerted counter-pressure on rising prices at the wholesale level where they could lower prices without losing the good will of retailers.

Between 1946 and 1948 Distillers Corporation-Seagrams Limited once again assumed leadership of the whisky industry. Seagrams increased its profits after taxes from $\$ 24,530,000$ in 1946 to $\$ 52,500,000$ in 1948, pushed its sales up fifty-three per cent while total sales for the industry fell twenty-five per cent, and in 1948 had control of thirty per cent of the U.S. whisky business. ${ }^{34}$ Whether this amazing success is even partially attributable to the policy litigated in the Kiefer-Stewart case apparently no one knows. It is certainly possible that such a program, pursued, as it was, on a nation-wide scale, ${ }^{35}$ would contribute to such results.

31 Hearings before Subcommittee of the Committee on the Judiciary on Sen. 206, 78th Cong. 1st Sess. 220-21 (1943). Midwest wholesalers often have no contracts; and their franchises, when written, contain ten-day cancellation clauses. Representatives of both Illinois and Indiana wholesale dealers termed the distillers' power one of "life and death." Concessions to retailers, which under resale price maintenance are pure profit and cannot legally be passed on to the consumer, are apparently still quite common. For a general discussion of the position of wholesalers and retailers in the whisky business see Abrahamson, Whiskey-The Incidence of Public Tolerance in Price Policy in Hamilton, Price and Price Policies 395, 417-20, 422 (1938).

${ }^{32}$ High unit margins have attracted large numbers into the retail liquor business even during times of falling consumption. Business Week at 70 (Feb. 5, 1949) reported that in New York, although sales volume at wholesale alone had dropped from 280 million in 1946 to 215 million in $1948,1,128$ new retail outlets had opened during the same period. In Indiana, according to the brief submitted by the Indiana Retail Package Liquor Stores Ass'n in support of Indiana House Bill No. 131 (Feb. 20, 1951) at page 4: "In 1940-41 about 3,500,000 gallons of distilled spirits were consumed. In 1949 that figure had fallen to 2,900,000 of distilled spirits. During the same period the number of package stores has increased in Indiana from 470 in 1940 to 800 stores in 1949." The number of wholesalers on the other hand, according to the Indiana Wholesale Liquor Dealers Ass'n, has not varied by more than one or two units since repeal. The wholesalers' mark-up, although once $17 \frac{1}{2}$ per cent, now rarely exceeds 10 per cent on an average.

33 "People are drinking about as much liquor in 1949 as they drank last year. But that's not particularly good news. For consumption in 1948 was $6 \%$ below 1947 . And 1947 was down a whacking 23\% off from 1946." Liquor Is a Price Problem, Business Week at 25 (July 9, 1949). See note 18 supra.

${ }^{34}$ Seagram in the Chips, 38 Fortune, No. 3, at 97 (Sept. 1948). See Younger Blends, Business Week at 22 (June 19, 1948).

${ }^{35}$ Testimony at the trial indicates the broad scope of Seagram and Calvert's "hold the line policy"; and the fact that these companies were carrying on an extensive advertising campaign 
II

Perhaps no other situation challenges the rationale underlying the per se rule more rigorously than maximum resale price-fixing by sellers. So dissimilar from cases previously decided under that rule ${ }^{36}$ did the Kiefer-Stewart situation appear, that the Court of Appeals for the Seventh Circuit apparently felt compelled to distinguish between illegal price-fixing and the Seagram-Calvert "agreement to prevent an increase in the resale price." ${ }^{37}$ Although such a distinction is conceptually unworkable ${ }^{38}$ it is not difficult to sympathize with the motives which inspired it. Price-fixing has been excoriated because it interferes with "the free play of market forces"; ${ }^{39}$ yet maximum resale price-fixing, as a means of overcoming monopolistic influences on lower levels of distribution, may prove extremely useful in the process of freeing those forces. If distributors were competitive, they themselves would drive prices down when demand conditions were such as to make lower consumer prices advantageous to the producer. ${ }^{40}$ The market situation underlying the Kiefer-Stewart case makes this motive to stimulate competition at distribution levels a quite probable explanation for the distillers' actions. Arguably, the ruling in Kiefer-Stewart, rather than promoting the economic policies embodied in the Sherman Act, may have disarmed manufacturers of one of their few weapons against monopolistic distributors. ${ }^{41}$

against inflated whisky prices seems to corroborate this. Transcript of Record 71-72, 253, Kiefer-Stewart Co. v. Seagram \& Sons, Inc., 340 U.S. 211 (1951). Not to be overlooked is the effect of Seagrams' vigorous general advertising program. Seagrams not only spends more on advertising than any other whisky-maker; but as well it stood eleventh among the largest advertisers in the United States in 1950. 58 Time, No. 23, at 100 (Dec. 3, 1951).

${ }^{36}$ The vast majority of cases involved minimum and absolute price-fixing by sellers. Of the Supreme Court decisions varying from this pattern, Swift \& Co.v. United States, 196 U.S. 375,392 (1905), upheld an indictment charging defendants with conspiring "to arbitrarily, from time to time raise, lower, and fix prices, and to maintain uniform prices"; but the Court did not discuss the maximum price-fixing charge and seems to have passed upon this aspect as part of a general scheme to monopolize the industry by exclusionary tactics.

${ }^{37}$ Kiefer-Stewart Co. v. Joseph E. Seagram \& Sons, 182 F. 2d 228, 235 (C.A. 7th, 1950).

${ }^{38}$ Nor is it reconcilable with the language in United States v. Socony-Vacuum Oil Co., 310 U.S. 150 (1940), where the definition of "price-fixing" was broadened to include not only the setting of specific minima or maxima but activities involving any form of tampering with market prices. The case itself involved practices which tended to drive market prices up but in no sense involved anything like the specific determination of price levels which ceiling-setting entails. Much earlier a Circuit Judge had stated: "It is clear ... that restraint of trade is not ... to be tested by the prices that result from the combination. Indeed, combination that leads directly to lower prices to the consumer may, within the doctrine of the cases, even as against the consumer be restraint of trade." United States v. Swift \& Co., 122 Fed. 522 (C.C. Ill., 1903), aff'd 196 U.S. 375 (1905).

${ }^{39}$ United States v. Socony-Vacuum Oil Co., 310 U.S. 150, 221 (1940).

${ }^{40}$ Resale Price Maintenance and the Anti-Trust Laws, 18 Univ. Chi. L. Rev. 369, 376 (1951).

41 Peppin, Price-Fixing Agreements Under the Sherman Anti-Trust Law, 28 Calif. L. Rev. 297, 667 at 731 n. 390 (1940), and see note 6 supra. Kiefer-Stewart argued quite effectively, however, that "police power cannot be exercised by a combination of private individuals. To permit them to do so would be to delegate the authority of the government to private parties 
The Court of Appeals was persuaded that defendants were "impaled on one prong of a two-horned dilemma." 42 Had Seagram and Calvert yielded to wholesaler pressure (and to the consequent inevitable demands for higher retail prices), they would have run the risk of antitrust prosecution for price-fixing with groups which, because of their horizontal organization, are not within the exemption afforded by the Miller-Tydings Amendment. 43 Nor could the distillers have brought a treble damage action against the conspiring wholesalers, as suggested by the Supreme Court, ${ }^{44}$ and continued to do business successfully in the areas where those wholesalers operated. Not only would it be impractical to set up outlets for distribution of a single brand; but also distillers are precluded by statute from doing their own distributing and from dealing with other than licensed wholesalers. ${ }^{45}$ Hence, according to the "dilemma" argument, distillers (and many other manufacturers) are effectively restricted to a choice between two forms of price-fixing, either of which entails potential antitrust liability after the Kiefer-Stewart decision.

If one assumes, tentatively, the existence of such a dilemma, there are cogent policy arguments favoring non-liability when a producer chooses to indulge in maximum price-fixing. Confronted with the risk of prosecution whether they yield to distributors or fight them, producers in a majority of instances will probably choose the former course. ${ }^{46}$ Evidential barriers to establishing that

and to deprive even suspected persons of the protection of the antitrust laws." Brief for Petitioner at 38, Kiefer-Stewart Co. v. Seagram \& Sons, Inc. 340 U.S. 211 (1951). Certainly the antitrust cases are on its side. Fashion Originators' Guild of America v. Federal Trade Commission, 312 U.S. 457 (1941); American Medical Ass'n v. United States, 130 F. 2d 233 (App. D.C., 1942). One does wonder, nevertheless, whether the distillers would ever find it advantageous to bring a treble damage action, especially when they must continue to sell through the same wholesale outlets.

${ }^{42}$ Kiefer-Stewart Co. v. Seagram \& Sons, Inc., 182 F. 2d 228, 234 (C.A. 7th, 1950).

${ }^{43}$ One of Seagram's subsidiaries, Frankfort Distilleries, had already suffered twice for participation in such vertical-horizontal agreements. "[W] hatever may be the rights of an individual producer under the Miller-Tydings Amendment to make price maintenance contracts or to refuse to sell his goods to those who will nol make such contracts, a combination to compel price maintenance in commerce among the states violates the Sherman Act." United States v. Frankfort Distilleries, Inc., 324 U.S. 293, 296 (1945). Connecticut Importing Co. v. Frankfort Distilleries, Inc., 101 F. 2d 79 (C.A. 2d, 1939). It is interesting to note that in these cases pressure for price maintenance appears to have originated in the wholesale and retail groups. Connecticut Importing Co. v. Continental Distilling Corp., 129 F. 2d 651 (C.A. 2d, 1942), contains a description of the manner in which even wholesalers were able to make their influence felt in forcing a distiller to enforce price maintenance.

- 44 Kiefer-Stewart Co. v. Seagram \& Sons, Inc., 340 U.S. 211, 214 (1951).

${ }^{45}$ See text and note at note 27 supra.

46 In a number of states, including Indiana, there is no choice, fair trade having been made mandatory for distillers. Indiana's requirement, introduced shortly after the events which culminated in the Kiefer-Stewart case, is imposed by regulations of the Indiana Alcoholic Beverage Commission as a prerequisite to "price and brand" liquor advertising. Brief for Respondents at 24 n. 11 and Transcript of Record at 215, Kiefer-Stewart Co. v. Seagram \& Sons, Inc., 340 U.S. 211 (1951). See notes 14 and 23 supra. 
fair trade agreements are in fact unlawful horizontal arrangements make successful prosecution by the Justice Department (or even private persons) less likely than suits by injured distributors, ${ }^{47}$ and the latter are certain to prove more expensive to producers. ${ }^{48}$ In an economy permeated with "fair" trade agreements which have seriously restricted the benefits of competition to ultimate consumers ${ }^{49}$ and increased the instability of the business community by adding immensely to the number of marginal distributors, ${ }^{50}$ the Supreme Court's decision would not seem to promote the ends which the Sherman Act was intended to serve.

But there are significant defects in the "dilemma" argument. First, nothing in the Supreme Court's opinion prohibits a single trader from fixing resale priceceilings-only conspiring to do so is proscribed; ${ }^{51}$ and therefore the dilemma described will confront only the trader who must conspire with another in fixing prices. This answer to the "dilemma" argument is not a cogent one. The concept "conspiracy" has been so extended by antitrust decisions as to make it doubtful that conspiracy would be found lacking in any resale price-fixing situation. It is well settled that illegal price-fixing conspiracies can exist between a parent and its wholly owned subsidiary; $;^{52}$ and it seems likely that such conspiracies will be found to exist among the officers of a single corporate entity.$^{53}$ Even more impor-

47 FTC, Report on Resale Price Maintenance LXI (1945).

${ }^{48}$ See Triple Damage-It's Murder, Business Week at 59 (April 22, 1950), and compare with the almost nominal (for big business) maximum fine per count recoverable in criminal actions against violators of the Sherman Act. 26 Stat. 209 (1890), as amended, 15 U.S.C.A. $\S 1$ (1951).

49 'It is obvious from the Miller-Tydings Act and the fair trade laws now flourishing in forty-five states that we don't want price competition in a large section of retail trade." Mason, The Current Status of the Monopoly Problem in the United States, 62 Harv. L. Rev. 1265 (1949). "[R]esale price maintenance, legalized to correct abuses of extreme price competition, is subject to use as a means of effecting enhancement of prices by secret agreements and restraint of competition by coercive action on the part of interested cooperating trade groups ... in such ways and to such an extent as to make it economically unsound and undesirable in a competitive economy." FTC, op. cit. supra note 47, at LXIV.

${ }^{50}$ See note 32 supra.

51 "Seagram and Calvert acting individually perhaps might have refused to deal with petitioner or with any or all of the Indiana wholesalers. But the Sherman Act makes it an offense for respondents to agree among themselves to stop selling to particular customers." Kiefer-Stewarl Co. v. Seagram \& Sons, Inc., 340 U.S. 211, 214 (1951).

${ }^{62}$ Schine Theatres, Inc. v. United States, 334 U.S. 110, 116 (1948) (conspiracy found among parent corporation, three officers and directors of the parent, and five wholly owned subsidiaries); United States v. General Motors Corp., 121 F. 2d 376 (C.A. 7th, 1941) (conspiracy found among GMC and two of its wholly owned subsidiaries, GMSC and GMAC); cf. United States v. Griffith, 334 U.S. 100 (1948) (conspiracy found among four affiliated corporations and two stockholder-officers); cf. United States v. Crescent Amusement Co., 323 U.S. 173 (1944) (conspiracy among nine affiliated companies); cf. United States v. Yellow Cab Co., 332 U.S. 218 (1947) (conspiracy among majority stockholder and partially owned subsidiaries).

${ }^{53}$ Cf. Lorain Journal Co. v. United States, 342 U.S. 143 (1951); and Schine Theatres, Inc. v. United States, 334 U.S. 110, 116 (1948). But see Justice Jackson's dissent in Timken Roller Bearing Co.v. United States, 341 U.S. 593, 606 (1951), where he says: "It is admitted that if 
tant for the Kiefer-Stewart-type case is the fact that, whenever maximum resale price-fixing is even partially successful, all the elements of an illegal agreement or concert of action between the producer and its complying distributors must be present; and the Miller-Tydings Amendment offers no immunity for maximum resale price-fixers. ${ }^{54}$

More serious defects in the "dilemma" argument are the probability of abuse of legalized maximum resale price-fixing, the rarity of situations in which it can be employed in overcoming illegal combinations of distributors, and the doubtful value to the general economy of even the latter activity. By persuading producers to impose resale price-ceilings on wholesalers, strong retail groups could cut wholesale prices to themselves and yet disguise their monopsony as producer-price-fixing, a practice which would certainly become popular if sellers' maximum resale price-fixing were not per se illegal. Possibly large and well-entrenched producers in an industry subject to extreme fluctuations might find it profitable to keep prices down in abnormal periods, thus sacrificing some shortrun profits to maintain price stability and avoid the rigors of competition over the long run. ${ }^{55}$ Again, this type of behavior would be compatible with a desire to avoid antitrust prosecution by cautious maneuvering away from the public limelight which often falls most glaringly on those who charge high prices and make large profits. ${ }^{56}$ Whatever the motives, in each of the above situations the

Timken had, within its own corporate organization, set up separate departments to operate plants in France and Great Britain [rather than subsidiary corporations] . . . 'that would not be a conspiracy. You must have two entities to have a conspiracy." "Perhaps corporate officers qua officers are not entities distinct from the corporation itself. But this would indeed be anomalous, for the fact that they were acting in an official capacity has not immunized corporate officers from personal liability under the Sherman Act (e.g., Schine case).

54 See note 5 supra.

${ }_{55}$ Such, for example, would be an acceptable explanation of facts revealed by the Celler Committee's inquiry into the newsprint industry. Although extreme shortages made possible a much higher return, newsprint manufacturers generally maintained low price ceilings and fought vigorously the resulting black market. At least one freely admitted to the Committee that the existing price, maintained by producer "self restraint," would discourage new capital investment. Testimony of James Zellerbach, President of Crown Zellerbach Corp., 6A Hearings before Subcommittee on Study of Mtonopoly Power of the Committee on the Judiciary, H. R. Rep. 81st Cong. 2d Sess. 916-17, 944-45 (1950). The Congressional investigation failed to reveal, however, why potential investors were not aware of the potential prices obtainable in the market; and the explanation of maximum price ceilings as a method of exclusion seems unsatisfactory for that reason. Nevertheless, it is the explanation publicly adopted by the Celler Committee. N.Y. Times $\$ 1$, p. 12, col. 1 (May 6, 1951); and Wall St. Jour., p. 2, col. 3 (May 5, 1951). A variant of this market tactic seems to have been employed by Alcoa to maintain its monopolistic position by making the business sufficiently unattractive so as not to be worth a battle with Alcoa's economic strength. United States v. Aluminum Co. of America, 148 F. 2d 416, 426 (C.A. 2d, 1945).

${ }_{56}$ The Newsprint investigation had overtones of this attitude as well. 6A Hearings before the Subcommittee on Study of Monopoly Power, op. cit. supra note 55, at 918-19. Such also would appear to be one of the motivations for the setting of price levels below obtainable market prices revealed in the recent steel investigation. $4 \mathrm{~A}$ Fearings before Subcommittee on Study of Monopoly Power of the Committee on the Judiciary, H.R. Rep. 81st Cong. 2d Sess. 733-35 (1950). 
effect of maximum resale price-fixing would be to obstruct rather than aid automatic market mechanisms in obtaining a desirable allocation of resources.

Only under the relatively rare circumstances of the principal case would a producer be likely to employ maximum resale price-fixing to combat illegal combinations of distributors. Ordinarily it would be a useless weapon against any combination whose power depends primarily on the manner in which some distributors can influence sales of a branded product by promoting nonprice factors -a common situation in resale price maintenance cases.$^{57}$ If maintained prices were reduced, such distributors would not only desire to push sales of competing products on which margins were larger but would, as well, tell consumers that lower prices were indicative of deterioration in quality. Defendants' actions in the instant case, however, are reconcilable with the existence of "consumer influence" monopolies at the retail level. By preserving the status quo in a period when wholesale and retail liquor prices generally were rising, it was possible for Seagram to maintain retail margins and nevertheless undersell the market..$^{58}$ If wholesale prices had risen as the wholesalers planned, Seagram would have had to contend with whatever consumer influence retailers might exert or submit to higher retail prices and lower sales volume.

Even as against a distributor combination, whose power results from state restrictive licensing and required dealing (as is probably the case with Indiana wholesalers), maximum resale price-fixing alone would hardly be effective in destroying this power and would need to be conjoined with offsetting monopoly power at the producer level. In the Kiefer-Stewart case, Seagram was probably using maximum resale price-fixing as a mechanism for exerting its own coercive market power to overcome that of the wholesaler combination. Without this monopoly power a producer probably could not enforce his demands for maximum resale price-fixing.

Stripped of its advocate's clothing, the "dilemma" argument is a naked demand that monopoly profits be distributed to different pockets. That the producer's monopoly power in this case may not be sufficient to bring it within the reigning interpretation of Section 2 of the Sherman Act, ${ }^{59}$ while the wholesaler

${ }^{57}$ See text at notes $139-44$ infra.

58 Kiefer-Stewart's version of economic occurrences during this period is much different from that described here. It claims that prices began to rise late in 1946 when supplies were scarce and that the decline occurred only in 1947 at which time Seagram and Calvert "executed and filed fair trade contracts perpetuating their former maximum prices as minima." Brief for Petitioners at 33, Kiefer-Stewart Co. v. Seagram \& Sons, Inc., 340 U.S. 211 (1951). This interpretation does not jibe with other data. In the middle of 1946 Barron's reported large whisky inventories and the prospect of sharp competition. Corrado, Bigger Whiskey Inventories, 29 Barron's at 7 (Aug. 26, 1946). At the time fair trade contracts were made not only were distillers being pushed by the new beverage commission regulation, but, as well, a 60 -day holiday had been declared on the manufacture of neutral spirits, which stimulated a buying spree in blends. Whisky Shortage? Business Week at 21 (Oct. 18, 1947). Petitioners' version would seem to attribute to Seagram's activities a type of irrationality not reflected in its sales and profits for the period. See text at note 34 supra.

${ }^{59}$ United States v. Aluminum Co. of America, 148 F. $2 d 416$ (C.A. 2d, 1945). 
combination is probably violative of the Act, should not work in the producer's favor. Quite commonly a method of exacting monopoly profit is held illegal when the monopoly is not. ${ }^{60}$

\section{III}

Kiefer-Stewart Co. v. Seagram \& Sons, Inc. is a far more significant decision when its facts are viewed in the limited perspective adopted by the Supreme Court. On a record totally devoid of evidence or findings that the defendants were capable of restraining competition by influencing the market price of whisky or that they actually produced an effect on the market, the Court held their agreement illegal per se. ${ }^{61}$ Indeed, the Kiefer-Stewart jury was expressly instructed that power and effect were wholly irrelevant to the illegality of a pricefixing agreement under the Sherman Act. ${ }^{62}$ Kept clearly before the courts, this ratio decidendi could serve in future antitrust litigation to relieve the govern-

${ }^{60}$ Standard Oil Co. of California v. United States, 337 U.S. 293, 310 (1949), presents an illustration of this principle recognized by the Court as such. There exclusive supply contracts with retailers were held illegal per se although the Court expressly admits that, if the retailers had been agents of the supplier, the arrangements would probably have been upheld.

Even better examples are the "Tie-in" cases such as International Salt Co. v. United States, 332 U.S. 392 (1947); Mercoid Corp. v. Mid-Continent Investment Co., 320 U.S. 661 (1944); Motion Picture Patents Co. v. Universal Film Mfg. Co., 243 U.S. 502 (1917), which preclude patentees from tying in unpatented articles with sales of patented products. The only satisfactory economic explanation for this behavior is that it represents a form of price discrimination. Where consumer demand for the patented article varies directly with the consumer's use of an unpatented article, it is possible to maximize profits by charging above-market prices for the unpatented article tied to the patented product. The increment above market price on the unpatented article is actually part of the price of the patented product. Despite the language of the courts, this is clearly exploitation of the sanctioned patent monopoly, not extension thereof.

Another example is the prohibition on resale price maintenance by a patentee under a crosslicensing plan, United States v. Line Materials Co., 333 U.S. 287, 314-15 (1947), although again the Court (probably erroneously) speaks of extension as opposed to exploitation of the patent monopoly. See Automatic Radio Co. v. Hazeltine, Inc., 339 U.S. 827, 838 (1950), upholding block patent licensing and a percentage-of-total-sales royalty agreement as mere exploitation of the patent monopoly over a vigorous protest "that the patentee received royalties on unpatented products as part of the price for the use of the patent."

61 The complaint contains allegations (probably inaccurate) that during 1940 through 1942 Distillers Corporation-Seagrams, Ltd., controlled 80 per cent of the spirit blend sales in the United States, spirit blends in 1946 representing 89.6 per cent of the whisky sold. Transcript of Record at 6-7. Although spirit blends represented only 48 per cent of the market when Seagram had 80 per cent control and by 1946 Seagram undoubtedly had a much smaller percentage, its power, even then, was probably sufficient to be felt in the market. But the salient parts of these allegations were denied in the answer (Transcript of Record at 18-19); and plaintiff made no attempt to repeat or substantiate them in the course of the trial.

62 'If, therefore, you find from a preponderance of the evidence that such a contract or conspiracy was entered into by the defendants for the purpose of fixing the resale prices of their products, then you shall find that such contract was illegal within the meaning of this statute, and it will not be necessary for you to go any further in to the reasons why it was illegal ... it is illegal within itself. ... You need not consider whether the prices so fixed were reasonable, nor whether the price-fixers controlled the market, or that some desirable ends were served." Transcript of Record at 267. For exception to the instruction see ibid., at 271, 354. 
ment, as well as private parties, of the tedious and expensive burden of presenting elaborate industry studies and expert economic testimony intended to demonstrate the effect and power of price-fixing combinations. ${ }^{63}$ Precedent makes it extremely doubtful that these relaxed evidential requirements will be considered applicable only in resale price-fixing cases. At the other extreme, a logical but dangerously expansive interpretation of Kiefer-Stewart could make those requirements applicable in every case properly arising under Section 1 of the Sherman Act, since almost every economic arrangement prohibited by that statutory provision has price affectation as an ultimate objective. ${ }^{64}$ For a prognosis of the extent to which the per se category is likely to be expanded, it is necessary to re-examine the evolution of the price-fixing rule of which KieferStewart represents a noteworthy development.

With some relatively insignificant exceptions, ${ }^{65}$ federal courts prior to 1911 struck down the price-fixing agreements which came before them. ${ }^{66}$ Evidence of

${ }^{03}$ For excellent descriptive discussions of the evidential problems involved in antitrust prosecution, see McAllister, The Big Case: Procedural Problems in Antitrust Litigation, 64 Harv. L. Rev. 27 (1950); Whitney, The Trial of an Anti-Trust Case, 5 Record of N.Y. Bar 449 (1950); Dession, The Trial of Economic and Technological Issues of Fact, 58 Yale L.J. 1019, 1242 (1949).

54 "In the cases considered by this Court since the Standard Oil Co. case in 1911 some form of restraint of commercial competition has been the sine qua non to the condemnation of contracts, combinations or conspiracies under the Sherman Act, and in general restraints upon competition have been condemned only when their purpose or effect was to raise or fix the market price." Apex Hosiery Co. v. Leader, 310 U.S. 469, 500 (1940).

65 United States v. Nelson, 52 Fed. 646, 647 (D.C. Minn., 1892) (upholding an agreement among midwestern lumber dealers to raise prices above the prevailing market because there was no allegation as to market effect and because the judge believed that no price-fixing agreement could be successful unless the parties controlled all of the commodity); Gibbs v. McNeeley, 102 Fed. 594, 596 (W.D. Wash., 1900) (agreements fixing prices and limiting production among producers of red cedar shingles held not illegal in absence of showing that prices or quotas were unreasonable); Dr. Miles Medical Co. v. Jaynes Drug Co., 149 Fed. 838 (C.C. Mass., 1906) (upholding a system of resale price maintenance between a patent medicine manufacturer and its jobbers and retailers); Rubber Tire Wheel Co. v. Milwaukee Rubber Works Co., 154 Fed. 358 (C.A. 7th, 1907) (upholding a system of resale price maintenance and production control between a patentee and his manufacturing licensees).

${ }^{65}$ United States v. Jellico Mt. Coal \& Coke Co., 46 Fed. 432 (C.C.Tenn., 1891) (resale price maintenance by all mine owners and dealers in Nashville area); United States v. Trans-Missouri Freight Ass'n, 166 U.S. 290 (1897) (agreement among competing railroads to maintain rates on traffic south and west of Missouri River); United States v. Hopkins, 82 Fed. 529 (C.C. Kan., 1897) (combination of all but one of the livestock commission merchants buying and selling at Kansas City Stockyards, the only available public market for a large number of states, to fix minimum commission rates); United States v. Coal Dealers' Ass'n of California, 85 Fed. 252 (C.C. Calif., 1898) (agreement among retail and wholesale coal dealers controlling between 75 and 90 per cent of the domestic fuel traffic in San Francisco to maintain prices and exclude price-cutters); United States v. Joint Traffic Ass'n, 171 U.S. 505 (1898) (agreement among competing railroads to maintain freight rates between Chicago and Atlantic coast); Addyston Pipe \& Steel Co. v. United States, 175 U.S. 211 (1899) (division of territory and price-fixing agreement among six major pipe manufacturers who, within the freight margin handicapping Atlantic seaboard manufacturers had a practical monopoly in thirty-six states); Chesapeake \& Ohio Fuel Co. v. United States, 115 Fed. 610 (C.A. 6th, 1902) (exclusive sales agency agreement among producers of 30 per cent of coal and 40 per cent of coke produced in 
power and effect, as well as purpose, was present in all the cases, however ${ }^{67}$ and it is not clear from the opinions which were considered necessary or sufficient. Arguably the Supreme Court's reliance on the word "every" in Section 1 of the Act indicated a desire to condemn all price-fixing agreements regardless of effect or the power of the combination.$^{68}$ On the other hand, in United States $v$. Trans-Missouri Freight Association Justice Peckham wrote:

In this light it is not material that the price of an article may be lowered. It is the power of the combination to raise $i t . .$. Nor is it for the substantial interests of the country that any one commodity be within the sole power ... of one powerful combination of capital. ${ }^{69}$

These words envision substantial, if not complete, control of the market as a basis for price-fixing illegality-not mere purpose alone. Subsequently the same court felt obliged to introduce a requirement that the restraint on commerce be of a direct nature "or else there would scarcely be an agreement or contract among businessmen that could not be said to have, indirectly or remotely, some bearing on interstate commerce, and possibly to restrain it."'70

During this period, then, despite rejection of the rule of reason, the Supreme Court appears to have been concerned with the obvious power and effect of the large combinations before it. Only in Judge Taft's statement of the common law -that "where the sole object of the parties in making the contract as expressed

Kanawha district of W.Va.); Ellis v. Inman, Poulsen \& Co., 131 Fed. 182 (C.A. 8th, 1904) (combination of only manufacturers of seasoned and kiln-dried lumber in Portland area refusing to sell to contractors who had purchased rough lumber elsewhere unless they paid difference in purchase price and the maintained price of combination's rough lumber); United States v. Swift \& Co., 196 U.S. 375 (1905) (conspiracy of midwestern meat-packers controlling 60 per cent of national meat production to fix prices and not to bid against each other on livestock markets); Leonard v. Abner-Drury Brewing Co., 25 App. D.C. 161 (1905) (attempt by four of five brewers in D.C. to compel fifth to raise his price through labor boycott struck down under common law); United States v. McAndrews \& Forbes Co., 149 Fed. 823 (S.D.N.Y., 1906) (price-fixing agreement between two manufacturers producing 85 per cent of licorice paste in United States); Continental Wall Paper Co. v. Voight \& Sons Co., 212 U.S. 227 (1909) (association of producers of more than 98 per cent of all the wall paper in the United States which fixed prices and regulated production).

67 There is some question about Chesapeake \& Ohio Fuel Co. v. United States, 115 Fed. 610,624 (C.A. 6th, 1902), where it was stated that the "law reaches combinations which may fall short of complete control of a trade or business and does not await the consolidation of many small combinations into the huge 'trust' which shall control the production and sale of a commodity."

68 "Every contract, combination ... or conspiracy, in restraint of trade or commerce among the several states . . . is hereby declared illegal." 26 Stat. 209 (1890), as amended, 15 U.S.C.A. $\$ 1$ (1951). "[T] that kind of contract alone which is in unreasonable restraint of trade, but all contracts are included in such language, and no exception or limitation can be added without placing in the act that which has been omitted by Congress." United States v. Trans-Missouri Freight Ass'n, 166 U.S. 290,328 (1897). Whether a particular agreement is "in restraint of trade," however, may be another matter.

69166 U.S. 290, 324 (1897). (Emphasis added.)

70 United States v. Joint Traffic Ass'n, 171 U.S. 505, 568 (1898). 
therein is merely to restrain competition and enhance or maintain prices, it would seem that there was nothing to justify or excuse the restraint"71-does one find real support for the proposition that general purpose alone is sufficient to sustain a charge of violating the Sherman Act.

Between 1911 and 1927 the direct price-fixing cases followed two distinctive patterns - systems of resale price maintenance and trade association arrangements. Beginning with Dr. Miles Medical Co. v. Park \& Sons, ${ }^{72}$ the Supreme Court, with but one minor deviation, ${ }^{73}$ held that agreements between a producer and his distributors to fix minimum resale prices were illegal under the Sherman Act. A majority of these cases involved rather obvious power and effect features, ${ }^{74}$ but in at least $t w o^{75}$ the Court seems to have verged upon a holding that a price-fixing purpose alone is illegal. In the Dr. Miles case the Court did not discuss the producer's general market position but contented itself with

71 United States v. Addyston Pipe \& Steel Co., 85 Fed. 271, 282 (C.A. 6th, 1898), where he adds: "Upon this review of the law and the authorities, we can have no doubt that the association of the defendants... however great the competition they had to encounter... was void at common law, because in restraint of trade, and tending to monopoly." Ibid., at 291.

72220 U.S. 373 (1911).

73 United States v. Colgate \& Co., 250 U.S. 300 (1918), came up on an indictment interpreted by the lower court as not charging an agreement but simply threats not to sell to distributors who sold below specified retail prices. The Court held that it was within the privilege of a property owner to sell to whom he pleased as long as he did not exact price maintenance agreements from his buyers. Although thoroughly limited by cases permitting agreements to be implied from a course of dealing, e.g., United States v. Schrader's Son, Inc., 252 U.S. 85 (1920), the Colgate case has shown amazing vitality in recent lower federal court decisions, e.g., Adams-Mitchell Co. v. Cambridge Distributing Co., 189 F. 2d 913, 916 (C.A. 2d, 1951); and Justice Black must have had it in mind when he wrote: "Seagram and Calvert acting individually perhaps might have refused to deal with petitioner or with any or all of the Indiana wholesalers. But the Sherman Act makes it an offense for respondents to agree among themselves to stop selling to particular customers." Kiefer-Stewart Co. v. Seagram \& Sons, 340 U.S. 211, 214 (1951).

${ }^{74}$ Standard Sanitary Mfg. Co. v. United States, 226 U.S. 20 (1912) (agreements between patentee and licensees controlling 85 per cent of the production of enamelled iron sanitary ware to fix jobbers' resale prices held illegal as outside the privileges of a patent monopoly); Straus v. American Publishing Ass'n, 231 U.S. 222 (1913) (attempt by 75 per cent of nation's publishers, urged on by an association representing a majority of booksellers, to refuse sale to department store not complying with resale price schedule is held illegal as to both copyrighted and uncopyrighted works); Ford Motor Co. v. Union Motor Sales Co., 244 Fed. 156 (C.A. 6th, 1917) (manufacturers of patented article not permitted to set price for resale by dealer purchasing on conditional sale); Boston Store of Chicago v. American Gramophone Co., 246 U.S. 8 (1918) (patentee not permitted to fix resale price on gramophone sold to retailer); United States v. Schrader's Son, Inc., 252 U.S. 85 (1920) (same); Frey \& Son, Inc. v. Cudahy Packing Co., 256 U.S. 208 (1921) (alleged conspiracy between manufacturer and jobbers of trademarked cleanser to maintain resale price held illegal, but reversed for error in instructions); Victor Talking Machine Co. v. Kemeny, 271 Fed. 810 (C.A. 3d, 1921) (patentee, wholesalers, and retailers). But see United States v. General Electric Co., 272 U.S. 476 (1926) (patentee permitted to fix resale prices on patented articles for wholesalers and dealers acting as its bona fide agents and to compel a manufacturing licensee to erect a similar system of resale price maintenance).

76 Dr. Miles Medical Co. v. Park \& Sons, 220 U.S. 373 (1911), and FTC v. Beech-Nut Packing Co., 257 U.S. 441 (1922). 
the fact that the agreements were made "with 'most of the jobbers and wholesale druggists of the country,' ... having for their purpose the control of the entire trade." ${ }^{\prime 76}$ In language reminiscent of Judge Taft's broad dictum referred to above, Justice Hughes stated that "agreements . . . having for their sole purpose the destruction of competition and the fixing of prices, are injurious to the public interest and void." ${ }^{\prime 77}$ As precedent for a literal rule of per se illegality, however, the case is quite vulnerable to distinction. Not only was it decided before Justice White's famgus pronouncement of the "rule of reason," "78 but it involved a "secret process" which may have been considered an element of market power comparable to a patent. Finally, recognizing that "the advantages of established retail prices primarily concern the dealers," $"$ not producers, the Court appears to have treated the plaintiff-producer as representative of a combination of dealers, ${ }^{80}$ in this case a large percentage of the nation's druggists. By their particularly influential form of consumer taste control, Dr. Miles' distributors may have been compelling resale price maintenance much as liquor retailers appear to do with their control of outlets and similar consumer influence. It is at least arguable that resale price maintenance under these circumstances involves significant market power and effect. ${ }^{81}$

More than offsetting the vague advances of Dr. Miles Medical Co. toward the Kiefer-Stewart position, Board of Trade of Chicago v. United States, ${ }^{82}$ upheld a grain exchange rule fixing, at the closing bid, prices between daily sessions on grain "to arrive." Justice Brandeis wrote:

But the legality of an agreement or regulation cannot be determined by so simple a test, as whether it restrains competition. Every agreement concerning trade, every regulation of trade, restrains. ... The true test of legality is whether the restraint imposed is such as merely regulates and perhaps thereby promotes competition or whether it is such as may suppress or even destroy competition. To determine that question the court must ordinarily consider the facts peculiar to the business to which the restraint is applied ... the nature of the restraint and its effect, actual or probable. ${ }^{83}$

${ }^{76} 220$ U.S. 373, 400 (1911). $\quad{ }^{77}$ Ibid., at 408.

${ }^{78}$ Standard Oil Co. of New Jersey v. United States, 221 U.S. 1 (1911).

${ }^{79} 220$ U.S. 373, 407 (1911). $\quad{ }^{80}$ Ibid., at 408-409.

${ }^{81}$ See discussion of the "separate market" theory of resale price maintenance in text at notes 139-44 infra. Decided long after the rule of reason had become imbedded in antitrust precedent, FTC v. Beech-Nut Packing Co., 257 U.S. 441 (1922), echoes the sweeping prohibition of resale price-fixing found in the Dr. Miles case. It is possibly distinguishable as an interpretation, not of the Sherman Act, but of the more specific prohibitions in Section $\mathbf{5}$ of the Federal Trade Commission Act, 38 Stat. 717 (1914), as amended, 15 U.S.C.A. $\$ 45$ (1951). More important, the opinion recognizes the market power aspects of resale price maintenance entered into "with the purpose and effect of securing the trade of such jobbers, wholesalers, and retailers, and of enlisting their active support and cooperation in enlarging the sale of respondent's products, to the prejudice of its competitors who do not require and enforce the maintenance of resale prices for their products." Ibid., at 445.

82246 U.S. 231 (1918).

${ }^{83}$ Ibid., at 238. Further, the Government was criticized for its failure "to show that the rule was designed to or that it had the effect of limiting the amount of grain shipped to Chicago ... or of raising or depressing prices." Ibid. 
Although the Board of Trade case makes it fairly clear that proof of all three -purpose, power, and effect-is prerequisite to the illegality of price-fixing agreements under the Sherman Act, its rigid evidentiary requirements were soon relaxed by American Column \& Lumber Co. v. United States. ${ }^{84}$ There the dissemination of elaborate statistics and "suggestions" as to prices and production by an association of lumber dealers controlling but one-third of the national hardwood production was held illegal. Lacking proof of a definite agreement as to production and prices, the Court considered this deficiency supplied by "the disposition of men to follow their most intelligent competitors." 85 Although less exacting than Justice Brandeis, Justice Clarke does not appear to have discarded the power and effect requirements but merely to have accepted less precise evidence, there being obvious attempts to demonstrate the market effect of the trade association's activities throughout the opinion. ${ }^{86}$

United States v. American Linseed Oil Co., ${ }^{87}$ involved similar activities (including a basing-point system of price-fixing) on the part of an association of linseed product manufactures and distributors controlling "a very large part" of the total linseed market. ${ }^{88}$ The combination was held illegal because "its necessary tendency [was] to suppress competition in trade between the states." 89

Justice Stone, who upheld comparable trade association activities in Maple Flooring Mfrs' Ass'n v. United States ${ }^{90}$ and Cement Mfrs' Protective Ass'n v. United States, ${ }^{91}$ distinguished the American Column and Linseed cases relying heavily on "the fact that the court inferred from the peculiar circumstances of each case that concerted action had resulted or would necessarily result in tending arbitrarily to lessen production or increase prices." ${ }^{\prime 92}$ It is possible that the Court intended the "necessary tendency" requirement to apply only where no express agreement among competitors could be shown; but the words themselves would seem rather to necessitate proof of market power on the part of the

81257 U.S. 377 (1921).

85 Ibid., at 399.

${ }^{86}$ Reference is made in a number of places to price increases during periods when the association was most active (ibid., at $407-409$ ) and to the satisfaction of the members with the results produced (ibid., at 405-407). "While it is true that 1919 was a year of high and increasing prices generally ... we cannot but agree with the members of the 'Plan' themselves ... in the conclusion that the united action of this large and influential membership of dealers contributed greatly to this extraordinary price increase." Ibid., at 409.

In a subsequent holding that the activities (which included price-fixing) of a combination of bill posters were violative of the Sherman Act, the Court was careful to state that the combination was so large it was "practically impossible for an advertiser to utilize posters except by employing members of the Association." Charies A. Ramsay Co. v. Associated Bill Posters, 260 U.S. 501, 510 (1923).

${ }^{87} 262$ U.S. 371 (1923).

88 Ibid., at 380 . 90268 U.S. 563 (1925).

${ }^{89}$ Ibid., at 389. 91268 U.S. 588 (1925).

22 Maple Flooring Mfrs' Ass'n v. United States, 268 U.S. 563, 585 (1925). 
parties to any price-fixing agreement, as was the case in Justice Stone's later opinions. ${ }^{93}$

Until 1927, then, with the possible exception of Dr. Miles v. Park \& Sons, Section 1 price-fixing cases before the Supreme Court generally contained evidence both of power to effect market forces and actual effect produced. The language of the opinions, although far from clear, indicates not only recognition of these elements but requirement of their presence before agreements as to prices would be condemned. Such clearly was Judge Learned Hand's interpretation in 1924 when he wrote: "We should have supposed that, if one thing were definitely settled, it was that the Sherman Act forbade all agreements preventing competition in price among a group of buyers, otherwise competitive, if they are numerous enough to effect [sic] the market." 94

Clarifying the trend of price-fixing law and corroborating a "power" interpretation of the "necessary tendency" doctrine in the trade association cases, United States $v$. Trenton Potteries $\mathrm{Co}^{95}$ is generally recognized as the first explicit formulation of the per se rule. Manufacturers and distributors of eighty-two per cent of the vitreous pottery bathroom fixtures produced in the United States combined to fix prices and limit outlets. Defendants alleged error in the trial court's refusal to submit the question of reasonableness of the prices fixed to the jury and in the charge that "an agreement on the part of the members of a combination controlling a substantial part of an industry, upon the prices which the members are to charge, is in itself an undue and unreasonable restraint of trade and commerce." $"$ In upholding this charge as a correct statement of the law, Justice Stone concluded that "uniform price-fixing by those controlling in any substantial manner a trade or business in interstate commerce is prohibited by the Sherman Law, despite the reasonableness of the prices agreed upon."

${ }^{93}$ In United States v. Trenton Potteries Co., 273 U.S. 392 (1927), which involved an express price-fixing agreement, Justice Stone limited the per se rule to combinations with substantial market control. In the Maple Flooring case, however, Justice Stone took pains to point out that it was "neither alleged nor proved that there was any agreement among the members of the Association either affecting production, fixing prices, or for price maintenance." 268 U.S. 563,567 (1925).

Upon a theory similar to that underlying Trenton Potteries, the Court in FTC v. Pacific States Paper 'Trade Ass'n, 273 U.S. 52 (1926), held illegal under Section 5 of the Federal Trade Commission Act an agreement to fix uniform prices to retailers made among wholesalers controlling 75 per cent of the paper sales in the Northwest.

94 Live Poultry Dealers' Protective Ass'n v. United States, 4 F. 2d 840, 842 (C.A. 2d, 1924)• (Emphasis added.) The general trend of antitrust cases at the time is reflected in United States v. U.S. Steel Corp., 251 U.S. 417, 450-51 (1920), which contains a clear holding that naked power in the absence of unlawful purpose or effect cannot constitute a violation of Section 2 of the Sherman Act. See also Butchart v. United States, 295 Fed. 577, 578 (C.A. 9th, 1924).

95273 U.S. 392 (1927).

86 Ibid., at 396. (Emphasis added.)

${ }^{97}$ Ibid., at 398. (Emphasis added.) Four years prior to Trenton Potteries, the Court had stated, by way of dictum, that a combination of railroad companies to fix reasonable rates 
Board of Trade case was distinguished as affecting "only a small proportion of the commerce in question" and "dealing ... with a regulation of a board of trade ... not ... a price agreement among competitors in an open market." 98

Despite later expansive interpretation, ${ }^{99}$ it must be clear that Trenton Potteries is precedent only for the proposition that price-fixing among parties capable of affecting the market is unreasonable per se. ${ }^{100} \mathrm{But}$, as a concomitant of this increased emphasis on the combination's power, where substantial control is proved, a conclusive presumption of market effect replaces the Board of Trade requirement that such effect be shown. This change greatly lightened the government's evidential burden by permitting a percentage of the market to be substituted for an elaborate statistical study of price behavior. ${ }^{101}$

Subsequent decisions sustain the power interpretation of Trenton Potteries. Upholding an agreement fixing royalty rates among owners of competing and conflicting patents, the Court, in Standard Oil Co. (Indiana) 0. United States, ${ }^{102}$ wrote: "In the absence of proof that the primary defendants had such control of the entire industry as would make effective the alleged domination of a part, it is difficult to see how they could by agreeing upon royalty rates control either the price or the supply of gasoline, or otherwise restrain competition."103 Not only does Justice Brandeis' opinion support the view that a price-setting agreement among parties without power to affect market prices is not "price-fixing" within the per se rule; ${ }^{104}$ but, as well, it indicates that (for the "lawyer's lawyer,"

sanctioned by the ICC might be illegal under the Sherman Act although not actionable by a private person, who, unlike the government, is limited to his remedy under the Interstate Commerce Act. Keogh v. Chicago \& Northwestern Ry. Co., 260 U.S. 156 (1922).

${ }^{98}$ Ibid., at 401 . Noteworthy is the fact that Justice Stone makes no attempt to distinguish the case in terms of intent or purpose as does Justice Douglas in United States v. SoconyVacuum Oil Co., 310 U.S. 150, 217 (1940).

99 United States v. Socony-Vacuum Oil Co., 310 U.S. 150, 225 n. 59 (1940).

${ }^{100} \mathrm{Wm}$. Dwight Whitney, who claims to have authored the per se rule in a Trenton Potteries brief, has written an interesting apology for the phrase which he states was intended only to convey the idea that activities which are obviously unreasonable restraints need not be proved to be unreasonable and was not intended to overrule the Board of Trade case. Whitney, The Trial of an Anti-Trust Case, 5 Record of N.Y. Bar 449, 454 (1950).

101 "The power to fix prices, whether reasonably exercised or not, involves power to control the market and to fix arbitrary and unreasonable prices. The reasonable price fixed today may through economic and business changes become the unreasonable price of to-morrow. ... Agreements which create such potential power may well be held to be in themselves unreasonable or unlawful restraints, without the necessity of minute inquiry whether a particular price is reasonable or unreasonable as fixed and without placing on the government in enforcing the Sherman Law the burden of ascertaining from day to day whether it has become unreasonable through the mere variation of economic conditions." United States v. Trenton Potteries Co., 273 U.S. 392, 397-98 (1927).
102283 U.S. 163 (1931).
${ }^{103}$ Ibid., at 179.

101"If combining patent owners effectively dominate an industry, the power to fix and maintain royalties is tantamount to the power to fix prices." Ibid., at 174. The Court bases its opinion largely on the "fact" that "cracked" gasoline and straight run gasoline (over which 
at least) the government continued to have a heavy evidential burden even if confined to a "definite factual showing" 105 of power to affect the market. Conceivably the Standard Oil (Indiana) holding is distinguishable by the presence of sanctioned patent monopolies; but no such criticism may be levelled at $A p$ palachian Coals, Inc. v. United States ${ }^{106}$ in which the Court refused to enjoin the establishment by otherwise competing coal producers of a common selling agency with price-fixing powers. Concluding from the evidence that the combination was powerless "to fix the price of coal in the consuming market," 107 the Court held that mere elimination of price competition between the parties without a showing of some injurious effect on the market was not sufficient to sustain a Section 1 indictment. Nevertheless jurisdiction was retained lest the plan should prove effective in operation.

Appalachian Coals can be interpreted as holding that purpose without power to fix prices is not per se illegal. As in Standard Oil (Indiana), the Court, rather than find a violation of the Sherman Act, attributes folly to defendants who certainly must have believed they could improve market prices. Aware that the parties intended to fix prices among themselves, ${ }^{308}$ the Court states that "[ $\left.t\right]$ he plan cannot be said to contemplate or involve the fixing of market prices."109

Possibly, then, the case may be distinguished from Kiefer-Stewart $v$. Seagram as involving bona fide "mitigation of recognized evils" try rather than a specific purpose to affect market prices. Recognizing that good intentions will not save a plan which results in actual injury to competition, the Court seems to have thought them relevant where no danger of such injury exists.111 Subsequent price-fixing cases coming before the Hughes' Court offered little opportunity to test this interpretation for they presented not only obvious examples of market power but findings of a dominant intent to fix prices as well. ${ }^{112}$

the defendants had much less contol) were indistinguishable and completely interchangeable. Aside from the dubious nature of the finding itself, it does not follow that the combination * could not affect prices if the cost of producing cracked gasoline were less than that of producing straight run, at least within the cost differential. Certainly it should have been presumed that the defendants acted in an economically rational fashion, i.e., attempted to reap a monopoly profit in the licensing field.

$$
{ }^{105} \text { Ibid., at } 179 . \quad 106288 \text { U.S. } 344 \text { (1933). } \quad 107 \text { Tbid., at } 373 .
$$

108 "The plan contemplates that prices are to be fixed by the officers of the Company at its central office." Tbid., at 358.

${ }^{109}$ Mbid., at 373. (Emphasis added).

$110 \mathrm{Ibid}$., at 374. Such was the distinction Justice Douglas later drew in United States v. Socony-Vacuum Oil Co., 310 U.S. 150, 216 (1940).

111 "Good intentions will not save a plan otherwise objectionable, but knowledge of actual intent is an aid in the interpretation of facts and the prediction of consequences." 288 U.S. 344,372 (1933).

112 Sugar Institute, Inc. v. United States, 297 U.S. 553 (1936) involved the activities of a trade association controlling 70-80 per cent of the refined sugar in the United States whose 
Hence up to 1940 the Supreme Court had refused in both dictum and holding to condemn agreements as to prices among parties who were not affirmatively shown to have affected the market or to have power sufficient to make market effect imminent and inevitable. In that year, while striking down an agreement among major midwestern petroleum refiners to buy up the distress gasoline of small, independent refiners then depressing the spot market, the Court indulged in language which cannot be easily reconciled with a power interpretation of the per se rule.

In a now famous footnote appended to United States v. Socony-Vacuum Oil Co., ${ }^{113}$ Justice Douglas wrote: "But that does not mean that both a purpose and a power to fix prices are necessary for the establishment of a conspiracy under $\$ 1$ of the Sherman Act. ... [A] conspiracy to fix prices violates Section 1 of the Act though no overt act is shown, though it is not established that the conspirators had the means available for the accomplishment of their objective, and though the conspiracy embraced but a part of the interstate or foreign commerce in the commodity." 114 This language is clearly dictum and wholly unnecessary to the decision, proof of effect on the market having been made (and acknowledged as essential to establish jurisdiction ${ }^{115}$ ) and the verdict for the government having arisen out of instructions which required the jury to find both power and effect.116

dominant purpose, the trial court found, was "to create and maintain a uniform price structure"; Interstate Circuit, Inc. v. United States, 306 U.S. 208 (1939) centered upon resale price maintenance by distributors of 75 per cent of the first-class feature films which an exhibitor with virtual monopolies in some Texas cities compelled them to enforce for the purpose of protecting its monopoly in first-run movies from the competition of subsequentrun houses; Ethyl Gasoline Corp. v. United States, 309 U.S. 436 (1940), concerned the substantially successful program of licensee-refiners controlling 80 per cent of the nation's gasoline production to compel resale price maintenance by their jobbers and price maintenance among themselves through their patentee, Ethyl.

Of the lower court antitrust decisions during this period, Connecticut Importing Co. v. Frankfort Distilleries, Inc., 101 F. 2d 79 (C.A. 2d, 1939), is noteworthy as declaring illegal, without discussion of power and effect, a conspiracy between a producer and its Connecticut distributors to maintain the price of whisky to retailers.

113 United States v. Socony-Vacuum Oil Co., 310 U.S. 150 (1940).

114 Ibid., at 225 n. 59.

116 "Under this indictment proof that prices in the Mid-Western area were raised as a result of the activities of the combination was essential, since sales of gasoline by respondents at the increased prices in that area were necessary in order to establish jurisdiction in the Western District of Wisconsin." Ibid., at 224 n. 59. See "F. The Spot Market Prices during the Buying Program." Ibid., at 194-98.

116 "The court charged the jury that it was a violation of the Sherman Act for a group of individuals or corporations to act together to raise the prices to be charged for the commodity which they manufactured where they controlled a substantial part of the interstate trade and commerce in that commodity. The court stated that where the members of a combination had the power to raise prices and acted together for that purpose, the combination was illegal. ... The court then charged that, unless the jury found beyond a reasonable doubt that the price rise and its continuance were 'caused' by the combination and not caused by those other factors, verdicts of 'not guilty'should be returned." Tbid., at 210-11. 
The Court in Socony-V acuum may not have intended to discard the power interpretation but simply to dilute the Trenton Potteries "substantial control" requirement. Such would seem to be the thrust of its argument distinguishing a direct price-fixing agreement (where power must be proved by showing substantial market control) from an agreement to affect market prices through a purchasing program (where "power may be found to exist though the combination does not control a substantial part of the commodity . . . . if as a result of market conditions, the resources available to the combinations, the timing and strategic placing of orders and the like, effective means are at hand to accomplish the desired objective.").117 Throughout the body of the opinion Justice Douglas appears to require that some element of power be shown to establish the illegality of a price-fixing arrangement even if that power must be inferred from the market effect of the agreement.

Had the sweeping dictum of footnote 59 never been written, Socony-Vacuum would stand for simply a logical extension of the Trenton Potteries decision. ${ }^{118}$ It would mean only that, unlike the authors of Standard Oil (Indiana) and Appalachian Coals, Inc., the Court will not presume that price-fixers have done an irrational or useless thing merely because they are shown not to have had substantial control of the market.119 If some peculiar quirk (as, for example, the manner in which price-leading Standard of Indiana ${ }^{120}$ religiously followed the small and easily manipulated spot market in determining its midwestern prices) should give parties lacking monopoly power the ability nevertheless to affect market prices, exercise of this power too would be illegal per se. ${ }^{123}$ But footnote 59 remains; and its reasoning by analogy to the general criminal law rule that conspiracy to commit an unlawful act is punishable regardless of the conspirators' power to achieve their object ${ }^{122}$ appears to have prevailed in $K$ iefer-Stewart v. Seagram.

${ }^{117}$ Tbid., at 223-24.

118 Judge Learned Hand seems to have espoused this interpretation in United States v. Aluminum Co. of America, 148 F. 2d 416 (C.A. 2d, 1945), where he cites the entire SoconyVacuum opinion for the power theory (at 427-28) but only footnote 59 for the argument concerning intent alone (at 432). In United States v. Imperial Chemical Industries, $100 \mathrm{~F}$. Supp. 504, 592 (S.D.N.Y., 1951), Judge Ryan cites footnote 59 directly for the proposition that market domination need not be proved to establish the illegality of price-fixing.

119 Answering Justice Brandeis' argument in the Standard Oil Co. (Indiana) case that no combination can "fix prices" unless it has the power to do so, Justice Douglas redefines pricefixing, saying that prices "are fixed when they are agreed upon." United States v. SoconyVacuum Oil Co., 310 U.S. 150 (1940). See text at note 104 supra. This, however, can be interpreted as meaning only that the presumption of power will be against the defendants.

${ }^{120}$ Standard of Indiana was dropped as defendant at the trial stage.

121 Justice Douglas probably had in mind the statement in Justice Roberts' dissent that the "evidence showed, without contradiction, that the Standard Oil Company of Indiana was the market leader in this area, and that when it posted its price none of the other defendants could sell at a higher price." United States v. Socony-Vacuum Oil Co., 310 U.S. 150, 257 (1940). Standard computed its retail prices on the basis of the spot market; and accordingly, by manipulating that price, defendants were able to influence the entire price structure. Ibid., at 192. The apparent artificiality of this situation is probably a product of litigation technique.

122 United States v. Rabinowich, 238 U.S. 78, 86 (1915). 
Footnote 59 is far from illuminating as to the exact nature of the purpose, proof of which is a sufficient substitute for evidence of market power or effect. From the manner in which Justice Douglas distinguished the Appalachian Coals and Board of Trade cases as involving price-fixing arrangements "not designed to operate vis-a-vis the general consuming market and to fix prices on that market," ${ }^{123}$ one could conclude that the government must show more than an agreement to fix prices inter se. Contributing to this interpretation is the opinion in Apex Hosiery Co. v. Leader, ${ }^{124}$ decided shortly after Socony-Vacuum. Holding that a sit-down strike which blocked interstate shipments was not a restraint of trade, Justice Stone argued that "in general restraints on competition have been condemned only when their purpose or effect was to raise or fix the market price. ... Restraints on competition ... in interstate commerce is not enough, unless the restraint is shown to have or is intended to have an effect upon prices in the mar$k e t$ or otherwise to deprive purchasers or consumers of the advantages which they derive from free competition." 125 If strictly adhered to, the Apex holding would require, in the absence of evidence of market power or effect, proof of a particular kind of price-fixing purpose-a purpose to affect market prices, not merely those charged by the parties to the agreement. Such an approach would be consonant with the criminal law requirement of proof of specific intent in conspiracy cases. ${ }^{125}$

Subsequent decisions, however, seem to hold that where, unlike the SoconyVacuum case, an explicit price-fixing agreement is shown, it is not necessary to

123310 U.S. 150, 216 (1940). The quoted statement was employed directly in distinguishing the Appalachian Coals case. Of the Board of Trade case Justice Douglas wrote: "Since it was not aimed at price manipulation or the control of the market prices and since it had 'no appreciable effect on general market prices,' the rule survived as a reasonable restraint of trade." Ibid., at 217.

124310 U.S. 469 (1940).

$225 \mathrm{Ibid}$., at 500 . (Emphasis added.) These words have been interpreted as applicable only where express agreements as to prices are not involved, Gundersheimer's Inc. v. Bakery \& Confectionary Workers' Internat'l Union of America, 119 F. 2d 205 (App. D.C., 1941); and, perhaps, even more narrowly, as applicable only to labor disputes, United States v. Nat'I Ass'n of Real Estate Boards, 339 U.S. 485, 489-90 (1950).

128 People v. Powell, 63 N.Y. 88 (1875); Harno, Intent in Criminal Conspiracy, 89 U. of Pa. L. Rev. 624, 629, 635 (1941). This statement assumes that, alone, the act of fixing prices inter se by parties without power to affect market prices is not illegal under the Sherman Act. Later cases, holding that this act constitutes a "restraint of trade," make it possible to apply the conspiracy rule to situations where the purpose of the parties is limited to fixing prices among themselves and involves no intent to affect market prices. See note 138 infra. Under the Apex case the limited act (i.e., fixing prices inter se without effect on market prices) would not be illegal unless accompanied with a broader intent (i.e., a specific intent to affect market prices or market power sufficient to supply such an intent). Dicta in two patent cases, Katzinger Co. v. Chicago Metallic Mfg. Co., 329 U.S. 394, 397 n. 3 (1947), and MacGregor v. Westinghouse Electric \& Mfg. Co., 329 U.S. 402, 405 n. 3 (1947), stating that even unexecuted price-fixing agreements would be illegal, are reconcilable with the Apex doctrine only if it is conclusively presumed that patentees have market power or believe they have such power. Although such a presumption would certainly be reasonable, Standard Oil of California v. United States, 337 U.S. 293, 307 (1949), the Court does not discuss the power or purpose of the parties and appears to assume that unexecuted price-fixing agreements by any parties would fall within the ban. 
prove an intent or purpose more wrongful than an intent to fix the prices to be charged by the parties. ${ }^{327}$ Except for United States 0. Nat'l Ass'n of Real Estate Boards, ${ }^{128}$ these decisions may be of little value as precedent because in the main they rest on clear and substantial proof of market power or effect. ${ }^{129}$ But as evi-

${ }^{127}$ E.g., United States v. Masonite Corp., 316 U.S. 265, 276 (1942): "Since there was pricefixing, the fact that there were business reasons which made the arrangements desirable to the appellees, the fact that the effect of the combination may have been to increase the distribution of hardboard, without increase of price to the consumer, or even to promote competition between dealers, or the fact that from other points of view the arrangements might be deemed to have desirable consequences would be no more a legal justification for price-fixing than were the 'competitive evils' in the Socony-Vacuum case"; United States v. National Ass'n of Real Estate Boards, 339 U.S. 485, 489 (1950): "Price-fixing is per se an unreasonable restraint of trade.... An agreement, shown either by adherence to a price schedule or by proof of consensual action fixing uniform or minimum price, is itself illegal under the Sherman Act, no matter what end it was designed to serve." See cases cited note 129 infra.

128339 U.S. 485 (1950). In this case the Supreme Court held illegal per se an agreement among members of the Washington (D.C.) Real Estate Board to adhere to schedules fixing minimum brokerage fees. Although the membership included only 250 of the 2000 real estate brokers in Washington, many non-members adhered to the non-mandatory schedules which, according to the trial judge, were intended to assure sellers that they were not being gouged by brokers. 84 F. Supp. 802,803 (1949). It seems doubtful that this group had marketpower sufficient to bring it within the Trenton Potteries "substantial control" test; but the decision may rest on reasoning similar to that found in some of the trade association cases-notably American Column \& Lumber. See discussion in text at notes 84-86 supra. However, the Supreme Court opinion is not concerned with the parties' economic power and probably represents as literal an interpretation of the per se rule as is found in the Kiefer-Stewart case.

129 United States v. Masonite Corp., 316 U.S. 265 (1942) (owner of controlling hardboard patent constituted all competing manufacturers and distributors del credere agents for sales at fixed prices; industry-wide organization held illegal as beyond patent reward); United States v. Frankfort Distilleries, Inc., 324 U.S. 293, 296 (1945) (combination of wholesalers and retailers controlling 75 per cent of spiritous liquors and wines consumed in Colorado charged with a price-fixing program the "effect, and if it were material, the purpose of [which] ... was to fix prices at an artificial level," found not within the Miller-Tydings exemption because involved horizontal agreements); United States v. Line Material Co., 333 U.S. 287, 312 (1948) (cross-licensing agreement between owners of complementary patents under which 40.77 per cent of dropout fuse cut-outs were made, permitting one to fix resale prices of all licensees, held illegal, such multiple agreements "establishing an intention to restrain" rather than merely exploit patent); United States v. U.S. Gypsum, 333 U.S. 364 (1948) (patent license agreements permitting licensor to fix minimum prices for the entire gypsum board industry including unpatented gypsum products held illegal); United States v. Paramount Pictures, 334 U.S. 131, 144 (1948) (agreement among exhibitors, distributors, and producers to fix minimum admission prices is held illegal per se as "part of the general plan to suppress competition."); Mandeville Island Farms, Inc. v. American Crystal Sugar Co., 334 U.S. 219, 222 (1948) (agreement fixing the prices paid to growers by three sugar refiners constituting the only "practical market available to beet growers" in northern California); United States v. Women's Sportswear Mfrs' Ass'n, 336 U.S. 460, 463 (1949) (agreement by women's sportswear jobbers to employ only stitching contractors who were members of association handling 50 per cent of sportswear produced in Boston, "the intent and effect of [which was] . . . substantially to restrict competition and to control prices and markets."); United States v. New Wrinkle, Inc., CCH 1952 Trade Reg. Rep. ๆ67,214 (1952) (industry-wide price-fixing by means of provisions in patent licenses granted by patent holding company to which two manufacturing concerns had assigned their patents on wrinkle paint finish).

United States v. Univis Lens Co., 316 U.S. 241 (1942) (owner of patents covering lens blanks and finishing process who sold blanks to distributor-finishers fixed resale prices of finished lenses; such price-fixing not exempted by Miller-Tydings Act which does not apply 
dence of a general trend toward a more literal interpretation of the per se rule their language and number, especially in the lower federal courts, is quite impressive. ${ }^{130}$ This movement toward an unconditional prohibition on express price-fixing agreements gained additional impetus from the treatment afforded the phrase "illegal per se" in recent important antitrust cases. In both United States v. Paramount Piciures, Inc. ${ }^{131}$ and United States v. Columbia Steel Co. ${ }^{132}$ illegality per se was distinguished from those situations in which power or a particular wrongful purpose must be shown. ${ }^{133}$

to sales to a processor); and United States v. Bausch \& Lomb Optical Co., 321 U.S. 707 (1944) (resale price maintenance agreements between distributor of unpatented lenses and its wholesalers and retailers held illegal per se), present power relationships more closely analogous to Kiefer-Stewart, although both involve minimum resale price-fixing.

${ }^{130} \mathrm{~A}$ sampling of the lower federal court decisions which have parroted a literal per se rule in fact-situations involving more or less obvious market power includes: Truck Drivers' Local No. 421, etc. v. United States, 128 F. 2d 227 (C.A. 8th, 1942); United States v. Sheffield Farms Co., 43 F. Supp. 1 (S.D.N.Y., 1942); Food and Grocery Bureau of S.Calif., Inc. v. United States, 139 F. 2d 973 (C.A. 9th, 1943); United States v. Spokane Fuel Dealers Credit Ass'n, Inc., 55 F. Supp. 387 (E.D.Wash., 1944); Triangle Conduit \& Cable Co. v. FTC, 168 F. 2d 175, 179 (C.A.7th, 1945); Alden-Rochelle, Inc. v. ASCAP, 80 F.Supp. 888 (S.D.N.Y., 1948); United States v. Maryland \& Virginia Milk Producers Ass'n, Inc., 179 F. 2d 426 (App. D.C. 1949); Pennsylvania Water \& Power Co. v. Consolidated Gas, Electric Light \& Power Co., 184 F. 2d 552 (C.A. 4th, 1950). For a more careful statement of the rule: Ring v. Spina, 148 F. 2d 647, 650 (C.A. 2d, 1945). In Maryland \&Virginia Milk Producers Ass'n, Inc. v. UnitedStates, 193 F. 2d 907, 916 (App. D.C., 1951), the Court of Appeals found in favor of producer-defendants alleged to have fixed prices by means of requirement contracts under which the dairies paid prices differing according to the use to which identical raw milk was put. In language similar to that of the Appalachian Coals case, the court held that mere stipulation of sales price in an ordinary sales contract could not be illegal per se unless "it gives to the contracting parties power which may be wielded to the disadvantage and detriment of the public and which may become oppressive as against competitors and tryannical as against consumers." The arrangement is probably explainable as a method of price discrimination on the consuming market by the sanctioned (agricultural association) producer-monopoly. See discussion note 60 supra.

131 "Exploration of these phases of the cases would not be necessary if, as the Department of Justice argues, vertical in tegration of producing, distributing and exhibiting motion pictures is illegal per se. But the majority of the Court does not take that view. In the opinion of the majority the legality of vertical integration under the Sherman Act turns on (1) the purpose or intent with which it was conceived, or (2) the power it creates and the attendant purpose or intent." 334 U.S. 131, 173-74 (1948).

132 "A restraint may be unreasonable either because a restraint otherwise reasonable is accompanied with a specific in tent to accomplish a forbidden restraint or because it falls within the class of restraints that are illegal per se." 334 U.S. 495, 522 (1948). There is no attempt in this language to define the restraints which are unreasonable per se. If an agreement regarding prices entered into by parties unable and not intending to affect market prices is not "pricefixing," then the statement that "price-fixing is illegal per se" does not alter the law as it was in 1940; and the statement above is perfectly consistent with such a definition.

${ }^{133}$ Illustrative of the extent to which a literal per se rule has taken hold, a line of patent cases holds that in a suit for royalties a patent licensee may not either expressly or impliedly be estopped by his license from setting up the invalidity of the patent if the license contains a pricefixing provision, because such a provision would be violative of the Sherman Act if the patent were invalid. Sola Electric Co. v. Jefferson Electric Co., 317 U.S. 173 (1942) (no implied estoppel); American Cutting Alloys, Inc. v. General Electric Co., 135 F. 2d 502, 504 (C.A. 2d, 1943) 
To this mass of dicta Kiefer-Stewart appears finally to add a direct holding. Reasoning not from available evidence of market power ${ }^{134}$ but from the evidence actually adduced on trial, one could not help but conclude that only the existence of an agreement, not market power and effect, was at issue in Kiefer-Stewart; and the jury instructions confirm this conclusion. ${ }^{135}$ The Supreme Court's peremptory rejection of Seagrams' argument that maximum resale price-fixing was its only practical weapon against illegal combinations of distributors ${ }^{136}$ indicates that benevolent intent is no longer a justification for price-fixing even in the absence of market power and effect. ${ }^{137}$ Broadly interpreted, Kiefer-Stewart is direct precedent for the proposition that, in the absence of statutory exemption, express price-fixing agreements are literally illegal per se. Indeed, Justice Black's identification of "restraint of trade" with restraint of individual traders' freedom opens even broader vistas of per se illegality. ${ }^{138}$

Possibly, however, the Kiefer-Stewart holding will be restricted to the resale price-fixing situation. ${ }^{139}$ Thus limited, the case arguably represents no extension

(no express estoppel); Katzinger Co.v. Chicago Metallic Mfg. Co.,329 U.S.394(1947) (no estoppel by express stipulation although price-fixing provision inserted at licensee's insistence); MacGregor v. Westinghouse Electric \& Mfg. Co., 329 U.S. 402, 405 n. 3 (1947) (footnote-dictum that even if unexecuted, agreements would be illegal). This would appear to assume that no more than the fact of agreement need be proved to establish illegality, although the presence of patents is "prima facie evidence of control." Standard Oil of California v. United States, 337 U.S. 293, 307 (1949).

134 See part I supra.

${ }^{135}$ See note 62 supra.

136 "If petitioner and others were guilty of infractions of the antitrust laws, they could be held responsible in appropriate proceedings brought against them by the Government or by injured private persons." Kiefer-Stewart Co. v. Seagram \& Sons, Inc., 340 U.S. 211, 214 (1951).

${ }^{137}$ This position is clearly contrary to earlier decisions allowing proof of benevolent purpose to negative any illegality in price-fixing among parties without power to affect the market. Board of Trade of Chicago v. United States, 246 U.S. 231, 237 (1918) (breaking up monopoly in that branch of the grain trade); Standard Oil Co. (Indiana) v. United States, 283 U.S. 163 (1931) (to reconcile conflicting patent claims); Appalachian Coals, Inc. v. United States, 288 U.S. 344 (1933) (to reduce "distress" coal, "pyramiding," and "cross-hauling" in a demoralized industry); and see Apex Hosiery Co. v. Leader, 310 U.S. 469 (1940) (bona fide wage dispute).

138 "For such agreements, no less than those to fix minimum prices, cripple the freedom of traders and thereby restrain their ability to sell in accordance with their own judgment." Kiefer-Stewart Co. v. Seagram \& Sons, Inc., 340 U.S. 211, 213 (1951). If the existence of restraints on individual traders' freedom is to determine the existence of restraints of trade, the absurd result is reached that all commercial contracts are illegal. Presumably "sell" refers to selling to persons not privy to the agreements. Maryland \& Virginia Milk Producers Ass'n v. United States, 193 F. 2d 907 (1951). But even this less literal construction of Justice Black's words reveals that the definition of "price-fixing" within the per se rule has radically expanded since the Board of Trade-Standard Oil (Indiana)-Appalachian Coals line of cases, which is beyond doubt completely rejected now. See text and notes at notes 102-12 supra. Should restraint on individual freedom in selling to others be considered a criterion for "restraints of trade" other than price-fixing, obviously the per se category has been considerably extended, although perhaps not beyond its existing bounds. See note 166 infra.

${ }^{139}$ An unsympathetic court would have no dificulty so limiting it. Broad language consonant with a literal per se rule appeared in the resale price maintenance cases both before and 
of prior law. Not only is its result encompassed within the broader interpretation of the Dr. Miles case; ${ }^{140}$ but the entire body of resale price maintenance precedent is, under one analysis, reconcilable with a power interpretation of the per se rule. Historically, and probably as a matter of economic necessity, resale price maintenance cases have involved only branded, trademarked, copyrighted, or patented products. ${ }^{141}$ If consumers treat these distinctively "labeled" products as unique, i.e., economically distinguishable from physically identical or easily substitutable commodities, a producer's exclusive control of their production may represent an economically significant form of monopoly power. Resale price maintenance is itself directed toward procuring the partial monopoly which distributors can create by reducing the sensitivity of consumers' reactions to fluctuations in the prices of substitutable (and even physically identical) commodities. ${ }^{142}$ By maintaining whoesale and retail profit margins, a price-maintaining producer may gain the services of distributors capable of altering the demand for his brand by their peculiar influence on consumer tastes and attitudes. ${ }^{143}$ Monopolies which are the result of consumer irrationality are nonetheless monopolies;144 and the power over the "separate market" for his branded product which a producer obtains by resale price-fixing should be sufficient to qualify as illegal under the "substantial control" test of Trenton Potteries or the "market effect" test posited in the Socony-Vacuum text.

The "separate market" theory of resale price-fixing illegality, however, has no application to maximum resale price-fixing which, as indicated above, ${ }^{145}$ may represent an attempted return to the very price competition which minimum and absolute resale price maintenance tends to destroy. Nor has there been express judicial recognition of the "separate market" theory even in cases the

after the Board of Trade case had imposed quite different standards in the direct price-fixing field. Dr. Miles Medical Co. v. Park \& Sons, 220 U.S. 373 (1911); FTC v. Beech-Nut Packing Co., 257 U.S. 441 (1922) (distinguishable as a construction of Section 5 of the Federal Trade Commission Act, 38 Stat. 717 [1914], 15 U.S.C.A. $\$ 45$ [1951]). United States v. Univis Lens Co., 316 U.S. 241 (1942), and United States v. Bausch \& Lomb Optical Co., 321 U.S. 707 (1944), are recent minimum resale price-fixing cases employing similarly broad language under Section 1 of the Sherman Act.

110 See text at notes 76-81 supra.

141 The Miller-Tydings Act exempts only resale price-fixing involving "a commodity which bears . . . the trade mark, brand, or name of the producer or distributor of such commodity." 50 Stat. 693 (1937), as amended, 15 U.S.C.A. $\$ 1$ (1951).

142 See the general discussion of cross-elasticity of demand and differentiated products in Stigler, The Theory of Price 88-90, 229-232 (1946).

${ }^{143}$ As one commentator puts it: "By setting a high enough retail price, the manufacturer can assure the dealers who 'advertise' his product a satisfactory profit by eliminating price competition from the 'free riding' low-cost retailers." Resale Price Maintenance and the Anti-Trust Laws, 18 Univ. Chi. L. Rev. 368, 377 (1951).

${ }^{144}$ Cf. Indiana Farmer's Guide Pub. Co. v. Prairie Farmer Pub. Co., 293 U.S. 268, 279 (1934); and United States v. Klearflax Linen Looms, Inc., 63 F. Supp. 32 (D.C. Minn., 1945).

${ }^{145}$ See text at notes $39-41$ supra. Certainly it would not be employed to obtain distributor good-will. 
facts of which appear to provide excellent examples of its practical operation. ${ }^{146}$ Finally, it is extremely doubtful that Kiefer-Stewart, or the trend of which it is representative, will be confined to resale price-fixing. Not only is the reasoning of the Supreme Court opinion, i.e., maximum resale price-fixing is illegal because it restrains traders' freedom, ${ }^{147}$ applicable to all other forms of price-fixing; but the sole authority cited for the price-fixing point was United States v. SoconyVacuum Oil Co., a direct price affectation case. Hence, in seeking the rationale underlying Kiefer-Stewart v. Seagram, it would seem wiser to interpret it broadly as striking down all express price-fixing agreements regardless of purpose, power, or effect.

\section{IV}

The justification for so sweeping a prohibition as the per se rule literally interpreted is not readily apparent. In its original form the rule was probably intended to be no more than a shorthand statement of the logic which made it unnecessary for the government to prove that the prices actually fixed were unreasonable. ${ }^{148}$ It having been determined that only contracts, combinations or conspiracies in unreasonable restraint of trade were violative of Section 1 of the Sherman Act, ${ }^{149}$ a logical leap could easily be made from the economic rationale of the Act itself to a holding that agreements shown to have affected market prices were unreasonable without further proof. ${ }^{150}$ Market price must be free of conscious manipulation if it is to perform its function in a competitive economy as sensitive indicator of individual values freely expressed and automatically reconciled. To impair the automatic functioning of this "central nervous system of our economy"161 is necessarily to restrain competition unreasonably, for to do so deprives the economy directly of that proper allocation of goods and resources which is the major social benefit of unfettered competition. But this rationale for the per se rule would be completely consonant with the Board of Trade case which requires the government to prove that price-fixing agreements have actually affected market prices.

${ }^{145}$ United States v. Univis Lens Co., 316 U.S. 241 (1942), and United States v. Bausch \& Lomb Optical Co., 321 U.S. 707 (1944). This peculiar feature of resale price maintenance has not gone unrecognized by the courts, however. One early court, in holding illegal the resale price maintenance scheme of a secret-formula-medicine manufacturer, found that "their prime purpose is neither protection of the retained business of the complainant nor of the wholesaler, but only to prevent competition among retailers." Park \& Sons Co. v. Hartman, 153 Fed. 24, 25 (C.A. 6th, 1907), where the court also expresses serious doubt that the producer receives any direct benefit from resale price-fixing. See similar language in Dr. Miles Medical Co. v. Park \& Sons Co., 220 U.S. 373, 408-409 (1911); and FTC v. Beech-Nut Packing Co., 257 U.S. 441, 445 (1922).

${ }^{147}$ Kiefer-Stewart Co. v. Seagram \& Sons, Inc., 340 U.S. 211, 213 (1951).

148 See note 100 supra.

${ }^{149}$ Standard Oil Co. of New Jersey v. United States, 221 U.S. 1 (1911).

${ }^{150}$ E.g., United States v. American Linseed Oil Co., 262 U.S. 371 (1923); United States v. Trans-Missouri Freight Ass'n, 166 U.S. 290 (1897).

151 United States v. Socony-Vacuum Oil Co., 310 U.S. 150, 224 n. 59 (1940). 
In this perspective the lighter burden imposed by the Trenton Potteries "substantial control" test appears as a judicial concession to the difficulty of tracing causal relationships in the complex reactions of a functioning economy. It simply states that an actual effect on market prices is reasonably and legally inferable from proof that the parties agreeing on prices among themselves have power to affect market prices. Rounding out this doctrine, the reasoning of the SoconyVacuum text ${ }^{162}$ permits an inference of cause (price-fixing by parties with market power) from effect (abnormal price rise or stability) or effect (price affectation) from cause (price-fixing by parties with market power) where the government can sustain a reasonable burden of proof as to the probability of some causal connection. As a matter of economic policy, however, price-fixing agreements among parties incapable of affecting market prices would seem innocuous; and hence it is probably necessary to look beyond that policy to understand the broader prohibitions embodied in the literal per se rule of footnote 59 and KieferStewart v. Seagram.

The peculiar characteristics of resale price-fixing which may account for the early appearance of literal per se language in the price maintenance cases may also serve as a guide to the underlying rationale of that doctrine. The only apparent explanations for minimum and absolute resale price-fixing as economic phenomena are in terms of purposes and activities which contravene the economic policy underlying the Sherman Act. Resale price-fixing may serve as a "signal-calling" device for oligopolistic producers, ${ }^{153}$ as a method of inducing restrictive combinations of distributors to favor certain brands as against others or at least treat them equally, ${ }^{154}$ or as a means of obtaining an economically significant monopoly in the market for a specified brand through distributor influence on consumers. ${ }^{155}$ In other words, from the standpoint of the antitrust laws nothing good may be said about the purposes for minimum and absolute resale price-fixing whether successful or not.

Of comparable significance is the practical impossibility in most cases of demonstrating that price maintenance activities have resulted in actual harm to the economy or even that the market power of the parties has made such injury highly probable. The growth of the concept "conscious parallelism" as a substitute for proof of express agreement is an example of judicial recognition of these

152 Tbid., at 223-24 (1940).

${ }^{15 z}$ Minimum and absolute resale price-fixing provide a smoothly functioning means of keeping tab on competing prices without resorting to trade association tactics. Similarly these devices can provide an effective method of keeping fellow oligopolists in line. Once a major producer succumbs to pressure for price maintenance others must follow suit or lose distributor good-will. "Although competing manufacturers cannot lawfully agree with each other respecting prices, they can accomplish the same result through resale price maintenance by making identical resale price agreements." FTC, op. cit. supra note 47, at LXII.

154 E.g., United States v. Frankfort Distilleries, Inc., 324 U.S. 293 (1945).

${ }^{165}$ United States v. Bausch \& Lomb Optical Co., 321 U.S. 707 (1941). It is quite likely that all three motives are operative in varying degrees wherever resale price maintenance is an industry-wide practice. 
evidential difficulties in the "signal calling" situation. ${ }^{166}$ In its "separate market" aspect as well, resale price maintenance, being essentially an advertising phenomenon likely to prove successful only where the consuming market displays highly irrational tendencies, raises nearly insurmountable evidential obstacles. The inscrutable nature of brand name appeal and distributor market influence make it extremely difficult to discover and prove the relative market position of the parties by means of the statistics ordinarily available to a prosecutor. ${ }^{157}$

Two characteristics, then-the unlikelihood of lawful purpose or results ${ }^{158}$ and the tremendous evidential burden which proof of power of effect would entail-appear both to account for and to justify the application of a literal rule of per se illegality to minimum and absolute resale price-fixing. An extension of this rule to the relatively rare case of maximum resale price-fixing is certainly not intolerable. Although, besides a number of unlawful or economically undesirable purposes, ${ }^{159}$ a maximum resale price-fixer could be seeking to overcome the restraints imposed by illegal combinations of distributors for the desirable purpose of indulging in price competition, adequate enforcement of the antitrust laws against such combinations would obviate the necessity for this device. It would seem anomalous, therefore, to reduce the effectiveness of a rule designed to facilitate enforcement of the antitrust laws by creating a confusing exception intended to remedy a defect which arises only because the antitrust laws are not adequately enforced. This argument becomes especially cogent where the creation of such an exception is likely to remove whatever motivation presently exists for private antitrust enforcement against horizontal combinations of distributors.

Nor are the reasons for a literal rule of per se illegality confined to resale price maintenance. Although the evidential burden may not be as great where other express price-fixing arrangements are involved, the paucity of lawful purposes or results would appear fairly comparable. It is difficult, if not impossible, to imagine a purpose for direct price-fixing among competitors which is not violative of the spirit of the Sherman Act; and hence it is unlikely that a literal per se rule would ensnare "innocents." From an economist's standpoint, price-fixing agreements among competitors incapable of affecting market prices are not only innocuous but probably also unexplainable in terms of rational economic motives. Indeed, economists might,argue that such agreements do not exist except where the parties are mistaken as to their power. From the standpoint of one attempting to enforce a set of economic regulations, however, such agreements may exist in the very significant sense that the rigid rules of evidence and limited presumptions make proof of power sometimes impractical or impossible. The

${ }_{166}$ Interstate Circuit, Inc. v. United States, 306 U.S. 208 (1939); United States v. Masonite Corp., 316 U.S. 265 (1942); United States v. U.S. Gypsum Co., 333 U.S. 364 (1948).

${ }^{167}$ Authorities cited note 63 supra.

158 "The case where a distributor fixes admission prices to be charged by a single independent exhibitor, no other licensees or exhibitors being in contemplation, seems to be wholly academic." United States v. Paramount Pictures, 334 U.S. 131, 144 (1948).

${ }^{159}$ See text at notes 55-60 supra. 
existence of a price-fixing agreement or conspiracy is ordinarily susceptible to a more certain and less intricate proof than either market power or market effect even where these factors are present. The judicial system is much better suited (or, at least, accustomed) to coping with such facts than with the industry studies, market statistics, and economic premises necessary in demonstrating market power or effect..$^{160}$ Even when market power and effect are not present, there is nevertheless ordinarily a need for prophylaxis if the probability of lawful purpose is as small as supposed above.

Certainly if proof of the agreement alone is sufficient to sustain a price-fixing indictment, the Antitrust Division has at least one more crutch with which to overcome the many practical handicaps of litigating against large corporations with a detailed knowledge of their private affairs never available to the government. ${ }^{161}$ Nor does a literal per se rule work solely in the government's favor. Its lighter, less expensive burden of proof favors self-interested private enforcement such as was had in the Kiefer-Stewart case; and, at the same time, its very simplicity and calculability should enable potential defendants to avoid violations of the Act.

If the policies embodied in the Sherman Act are worth effectuating, they deserve rigid enforcement even at the expense of perfect justice. As Justice Peckham warned in exhorting against the rule of reason, should the evidential burden of the plaintiff become too great in antitrust litigation, enforcement must be relegated to the unreliable commercial conscience. ${ }^{162}$ When our legal system proves unequal to the task of maintaining competition, the body politic has and will again turn to administrative regulation of monopoly and thence to monopolizing on its own. ${ }^{163}$ These consequences are as antithetical to the political and economic ideals which the Sherman Act embodies as is the existence of private monopoly. ${ }^{164}$

160 Classic examples of important antitrust suits made to turn on legalistic verbalisms wholly irrelevant to the economic consequences of the practices involved are such cases as United States v. General Electric Co., 272 U.S. 476 (1926); and United States v. Richfield Oil Corp., 99 F. Supp. 280 (S.D. Calif., 1951), whose results depended solely upon the existence or nonexistence of an agency relationship.

161 Authorities cited note 63 supra. Despite these difficulties it is, perhaps, significant to note that the Government has not yet chosen to rely on the relaxed evidential standards of footnote 59 in prosecuting its price-fixing charges. E.g., cases cited note 129 supra.

162 United States v. Trans-Missouri Freight Ass'n, 166 U.S. 290, 331-32 (1897).

162 "Courts are ill-equipped to apply a rule which is more economic than legal in nature and which necessitates the minute examination of many subtle factors. An erroneous determination by the Court, exculpating incipient monopolies, will have dangerous social consequences. The inadequate and sporadic nature of judicial control might eventually make more thoroughgoing governmental supervision necessary. No suppression of competition, however minute, could long continue without such regulation. To supervise and regulate the multitudinous arrangements that would be made were the dictum of the Appalachian Case to become the established rule would impose an administrative burden upon government which could only be justified by indubitably clear social and economic gains." Handler, Construction and Enforcement of the Federal Antitrust Laws 34-35 (TNEC Monograph 38, 1941).

184 ' If the so-called competitive abuses were to be appraised here, the reasonableness of prices would necessarily become an issue in every price-fixing case. In that event the Sherman 
But it should be remembered that the per se rule is designed essentially to reduce the evidential burden in antitrust prosecution, not to enlarge the purview of substantive law. Totally unleashed, it could engulf in illegality every business contract stipulating prices and involving interstate commerce. ${ }^{165}$ It should be confined to cases where the likelihood of unlawful purpose or result is as great as in the case of direct price-fixing among competitors. ${ }^{166}$ Where market effect or power to produce one has not been proved, the defendant should be permitted to justify his action with evidence of lawful purpose unless the probability of such purpose is too small to be worth the difficulties inherent in proving its existence or nonexistence.

Roughing out the categories of acts where a literal rule of per se illegality should be applicable is, of course, a case-by-case process; but if case analysis proceeds explicitly in terms of a criterion comparable to probability of lawful purpose, the course of decisions should not be difficult to predict. In as complex a situation as the Socony-Vacuum buying program, for example, if no power or effect were shown, little could be lost by making the presumption of unlawful purpose prima facie only, while much might be gained by giving entrepreneurs maximum freedom in choosing their methods of competition. As Justice Jackson has said: "If the courts are to apply the lash of the antitrust laws to the backs of businessmen to make them compete, we cannot in fairness also apply the lash whenever they hit upon a successful method of competing." ${ }^{167}$

Act would soon be emasculated; its philosophy would be supplanted by one which is wholly alien to a system of free competition; it would not be the charter of freedom which its framers intended." United States v. Socony-Vacuum Oil Co., 310 U.S. 150, 221 (1940).

${ }^{165}$ See note 138 supra.

${ }^{166}$ A remarkable parallel to the evolution of the price-fixing rule may be traced.in the "forestalling" cases which involve agreements for exclusive dealing, boycotts, and patent tie-ins of unpatented materials. Such agreements may no longer be justified as directed against illegal activities of the foreclosed groups, Fashion Originators' Guild of America v. FTC, 312 U.S. 457 (1941); American Medical Ass'n v. United States, 130 F. $2 d 233$ (App.D.C., 1942); and after a series of cases apparently requiring proof of market power (domination) to meet the requirements of Section 3 of the Clayton Act and Section 1 of the Sherman Act, Standard Fashion Co. v. Magrane-Houston Co., 258 U.S. 346 (1922); Pearsall Butter Co. v. FTC, 292 F. 720 (C.A. 7th, 1923); FTC v. Gratz, 253 U.S. 421 (1920), the Court has finally concluded that "it is unreasonable, per se, to foreclose competitors from any substantial market" and that a market is "substantial" if the "volume of business affected . . . cannot be said to be insignificant or insubstantial." International Salt Co. v. United States, 332 U.S. 392, 396 (1947). Justice Frankfurter candidly admits in Standard Oil of Califormia v. United States, 337 U.S. 293 (1949), that a rule of per se illegality rather than a rule testing the economic consequences of such arrangements was adopted because "tying agreements serve hardly any purpose beyond suppression of competition" (305) and the latter rule would require "a standard of proof, if not virtually impossible to meet, at least most ill-suited for ascertainment by courts." Ibid., at 310. Although explicitly confined to the Clayton Act in the Standard of California opinion (ibid., at 311-13), this reasoning is certainly applicable to violations under Section 1 of the Sherman Act. United States v. Richfield Oil Corp., 99 F.Supp. 280, 286, 296-97 (S.D.Calif., 1951).

${ }^{167}$ Standard Oil of California v. United States, 337 U.S. 293, 324 (1949). 